İş ve İnsan Dergisi I The Journal of Human and Work

Y1l | Year: Ekim | October 2019

Cilt-Say1 | Volume-Issue: 6 (2)

ss I pp: 209-227

doi: 10.18394/iid.525432

e-ISSN 2148-967X

http://dergipark.gov.tr/iid/

Derleme Makalesi

\title{
Sağlık Çalışanları Arasında Panoptik Korku
}

\author{
Panoptic Fear among Health Workers
}

MAKALE BİLGISİ

Anahtar Kelimeler:

Gözetim, Panoptikon,

Caydırıcı Etki, Să̆lık

Hizmeti, Panoptik Korku

Tarihler :

Geliş 11 Şubat 2019

Düzeltme geliş 26 Haziran

2019

Kabul 05 Ağustos 2019
ÖZ

\begin{abstract}
Insanlar her dönemde gözetim mekanizmalarını kullanma ihtiyacı hissetmiş olup modern dönemle birlikte modern gözetim tekniklerine duyulan ihtiyaç çarpıcı bir şekilde artış göstermiştir. Günümüze doğru gelindiğinde gözetim faaliyetinin sağllk hizmetleri alanında yoğun olarak kullanıldı̆̆ı söylenebilir. Sağlık çalışanları çok çeşitli uygulamalar ile sürekli olarak gözetlenmekte, hastane yönetimlerinin norm ve beklentilerine uygun normalize edilmiş profesyonel davranışları teşvik edilmektedir. Söz konusu gözetimin profesyonellerde herhangi bir korkuya dönüşüp dönüşmediği ise henüz araştırllması gerekli bir alan olarak karşımızda durmaktadır. Buna ek olarak, sağlık hizmetleri alanında gözetim ve davranış ilişkisini Foucault'çu yaklaşımla ele alan herhangi bir çalışmaya rastlanmamıştır. Bu çalışmada, sağlık hizmetleri alanında çalışanlar üzerinde panoptik gözetimin yaratacă̆ korku ve buna yönelik olarak geliştirilecek davranışlar Bentham ve Foucault'un yaklaşımları benimsenerek ilgili literatür ışığında değerlendirilmiştir. Çalışmamızda panoptik gözetim - panoptik korku ve davranış ilişkisini araştırmak için hatırı sayılır nicelikte gelişmenin yaşandı̆̆ına dikkat çekilerek gözetim konusunda sağlık hizmetleri alanının sosyologlardan pek çok şey öğrenebileceği gerçeği ortaya konmaya çalışılmıştır.
\end{abstract}

\section{ARTICLE INFO}

\section{Keywords:}

Surveillance, Panopticon, Chilling Effect, Health Care, Panoptic Fear

Article history:

Received 11 February 2019 Received in revised form 26 June 2019

Accepted 05 August 2019

\begin{abstract}
A B S T R A C T
People have been felt the need of surveillance mechanisms at all times. The need for modern surveillance techniques has increased dramatically in the modern era. When it comes to today, it can be said that surveillance activity has been used extensively in health care. Health workers are continuously monitored with applications, and normalized professional behaviors are promoted. Whether the surveillance has turned into a fear among professionals is still a field to be investigated. Besides, we have found no study deals with surveillance and behavior in health care carried out with Foucauldian approach. In the study, the fear of panoptic surveillance on healthcare workers and the behaviors to be developed concerning this were evaluated in the light of relevant literature by adopting the approaches of Bentham and Foucault. It has been tried to reveal there is considerable amount of development to investigate the relationship between panoptic surveillance and panoptic fear and behavior, and health care can learn a lot from sociologists about surveillance.
\end{abstract}

\footnotetext{
a İletişim kurulacak yazar, Arş. Gör. Hacettepe Üniversitesi, İktisadi İdari Bilimler Fakültesi, Sağlık Yönetimi Bölümü, Ankara, Türkiye. E-mail: huseyindemir@hacettepe.edu.tr.ORCID:0000-0002-8990-7228

b Doç. Dr., Dicle Üniversitesi, İktisadi İdari Bilimler Fakültesi, Siyaset Bilimi ve Kamu Yönetimi Bölümü, Diyarbakır, Türkiye. E-mail: yilmaz.demirhan@dicle.edu.tr.ORCID:0000-0003-3762-7387
} 


\title{
1. GİRIŞ
}

\begin{abstract}
$\mathrm{X}$ bir hastane idaresinin çalışanlarının mesai saatlerine uyup uymadığını takip etmek amacıyla görev yerine giriş çıkışta personel kartlarını okuyan bir cihazdan yararlandığını düşünelim. Personelin bir kısmı bu kontrolün görevliler marifetiyle yapılmamasına istinaden düzenli bir kontrolün olmayacağını düşünerek kartlarını cihaza okutturma konusunda gevşeklik göstermiş olsun. Ve böylece bu personel için belli günlerde mesaiye geç gelme veya erken ayrılma ya da hiç göreve gelmeme yönünde bir durum ortaya çıksın. Buna binaen idare ilgili personelden bu durumun sebebini soran ve savunmasını vermesini isteyen bir ihtarname göndersin. Böyle bir durumda çalışan, fiziken bir görevli tarafından gözetilmese de kurulan bu mekanizma vasıtasıyla mesaisinin düzenli ve sürekli bir şekilde kontrol edildiği gerçeğini idrak edecek ve böylece işe devam noktasında belki de daha hassas davranacaktır.
\end{abstract}

Deneysel İktisat alanındaki çalışmaları nedeniyle 2017 y1lında TÜBİTAK Bilim ödülüne layık görülen Koç Üniversitesi Ekonomi profesörlerinden Sumru Altuğ, kendisi ile yapılan bir röportajda "ekonomiyi ekonomi yapan, bireyin davranışlarıdır" ifadesini kullanmıștırc. Altuğ'un iktisat alanı için kullandığı bu söz şüphesiz pek çok alan ve hizmet için geçerlidir. $\mathrm{Bu}$ ifadeler belki de en çok sağlık hizmetlerinde karşılık bulmaktadır. Biz de Altuğ'un bu söyleminden esinlenerek, "sağlık hizmetini sağlık hizmeti yapan, sağlık profesyonellerinin davranışlarıdır" şeklinde bir ifade kullanmak istiyoruz. Bir ülkede sağlık hizmetlerinin standardını belirleyen en önemli ölçütlerin başında sağlık kuruluşlarında çeşitli sağlık hizmetlerini üstlenen sağlık profesyonellerinin davranışları gelmektedir. Yukarıda hayali olarak tasarlanmış örnek olayda da görüldüğü üzere, bireyin davranışlarını içsel ve dişsal faktörler belirlemektedir. Kişiler ya içten gelerek kendiliğinden kurallara tabi olurlar veya dıștan bazı zorlamalarla istenilen yönde davranış ortaya koyarlar. Burada davranışı belirleyen şey ise kişinin gözetlendiğinin farkında olmasıdır. Ancak bu gözetim her zaman kișinin pozitif yönde davranış göstermesini sağlamayabilir. Bazen sürekli bir gözetim kişide kayg1 ve strese yol açarak onun olumsuz davranışlar sergilemesi yönünde bir hal ortaya çıkarabilir.

Gözetim ve denetim tarihin her döneminde var olmuştur ancak bilgi ve iletişim teknolojilerinin gelişimi ile karakterize edilen modern dönemle birlikte gözetim ve denetim aygıtları farklı şekillerde karşımıza çıkmaya başlamıştır (Bauman, 2017a). Geçtiğimiz yüzyılın etkili isimlerinden Foucault (1979) modern gözetimi tasvir etmede "panoptikon" metaforunu kullanmıştır. Foucault'a göre modern dönemle birlikte gözetim ve denetim anlayışı ilkel olmaktan çıkıp modern bir nitelik

Söz konusu röportaja https://www.youtube.com/ watch?v=cOrEetJ67Mc adlı internet adresi kullanılarak erişim sağlanmıștır. Erișim Tarihi: 15.11.2018. kazanmıștır. Panoptikon modelinde insan davranışları üzerinde iktidar(lar) veya otorite tarafindan norm ve beklentilere uygun etki yaratılması ve kişilerin otoritenin beklentileri yönünde harekete geçirilmesi durumu söz konusudur (Foucault, 1979, 1980). İnsan davranış1, şüphesiz sağlı hizmetleri alanı için ayrıcalıklı önem arz etmektedir zira sağlık hizmetlerinde söz konusu olan husus hastanın sağlığıdır ve hasta sağlığını olumsuz olarak etkileyebilecek davranışların saptanması, normalize edilmesi ve iyileştirilmesi gerekmektedir. Gözetim mekanizması bu yönüyle sağlık alanı için önemli sonuçlar üretebilmektedir.

Gözetim ve insan davranışı arasında kurduğu ilişkiden dolayı (Goffman, 1959; Lashmar, 2017; Pen American Center, 2013) panoptikon yaklaşımının sağlık hizmetleri alanı için önem arz ettiği ve alanda karşılık bulduğu söylenebilir. Sağlık hizmetleri alanı yakından değerlendirildiğinde, gözetim aygitlarının bu alanda yoğun bir şekilde kullanıldığı ve çalışanlar-arası etkileşimde önemli etkiler yarattığı anlaşılmaktadır (De Choudhury vd., 2014; Foucault, 1980). Toplam kalite uygulamalarından yalın yönetime, performansa dayalı ücret sisteminden global bütçe uygulamalarına ve hastane otomasyon sistemlerine kadar birçok teknoloji kullanılarak sağlık çalışanları sürekli olarak gözetlenmektedir. Yerli literatürde gözetim ile ilgili çeşitli çalışmalar bulunmaktadır. Bozalp (2018), modernizmin gözetim için oldukça önemli olduğuna ve teknik gelişmeler ile birlikte toplumun disipline edilmesinde sistemli gözetim faaliyetinin söz konusu olmaya başladığına işaret etmektedir. Akyazı (2019), mahremiyetin dönüşümünü gelișen teknolojiler bağlamında ele alarak sosyal medya uygulamalarının gözetimdeki yeri ve önemine dikkat çekmiştir. Abalı (2018), aile hekimliği bilgi sistemini mahremiyet ve gözetim ilişkisi bağlamında ele alarak bu uygulamaların gözetim pratikleri ile ilişkisini ele almıştır. Durutürk (2018), çalışmasında iktidar, özne ve birey arasındaki ilişkinin nasıl ortaya çıktığını 
Foucault'un yaklaşımı ile ele almıștır. Bulut (2019), gözetim hususunda dünya gündemine konu olan Edward Snowden'ın 2013 yılının Mayıs ayında Amerika'nın ilgili birimlerinin dünya genelinde kamusal ve kişisel bilgileri nasıl gözetlediğine ilişkin bilgi ve belgeleri medyaya ifşasını kapsamlı olarak ele alarak yapılan bu girişimi meşru bir direniş ve kamusal yararı bulunan bir hareket olarak değerlendirmiştir. Öztürk (2019), Bora Ataman ve Barış Çoban tarafından derlenen, "Panoptikon 2.0: Alternatif Medya ve Karşı Gözetim” adlı kitabın incelemesi olarak tasarladığı çalışmasında teknolojinin gelişimi ile birlikte gözetimin güç kazandığını ve buna karşılık olarak ortaya atılan karşı gözetim kavramını etraflıca ele alarak yaşanan değişimin önemine işaret etmektedir. Buna karşın, konuya ilişkin yazın yakından incelendiğinde görebildiğimiz kadarıyla, sağlık hizmetleri alanında panoptik gözetim - panoptik korku ve davranış ilişkisini araştıran herhangi bir çalışmaya rastlanmamıştır. Sağlık hizmetleri alanında kullanılan uygulamalar ile sağlık çalışanları arasında panoptik korku oluşturma riski ve buna yönelik davranışların geliştirilmesi ihtimali bu çalışmanın çıkış noktasını oluşturmaktadır. Çalıșma kapsamında yapılan tartışma ve değerlendirmelerle çalışmanın araştırma sorusunu oluşturan "panoptik gözetim sağlık çalışanlarında panoptik korku ve davranış geliştirmeye neden oluyor mu?" sorusuna cevap aranmaya çalışılmıştır. Çalışmamız, insan üzerinde önemli etkileri bulunan korku duygusunun - Bauman'ın (2017a) deyimiyle özellikle de akışkan modern korkunun - sağlık çalışanları üzerinde etkisi ve olası sonuçlarının panoptik perspektif ile değerlendirilmesi ve "panoptik korku" kavramının ilk kez sağlık yönetimi yazınında kullanılması yönünde mütevazı bir girişimi amaçlamaktadır. Bu yönü ile çalışmanın özgün bir değere sahip olduğu düşünülmektedir. Çalışma, sağlık hizmetleri alanında ihmal edilmiş bir alan olan gözetim hususuna dikkat çekmek ve gözetimin sağlık profesyonelleri üzerindeki etkilerini eleştirel bir yaklaşımla ele alarak söz konusu profesyonelleri gözetlerken sağlık yöneticilerinin daha hassas olmaları konusunda dikkatlerini celp etmeyi hedeflemektedir. Sosyoloji alanında çok sayıda araştırmacının araştırmaya konu olan gözetim kavramının çeşitli örneklerle desteklenerek sağlık hizmetleri alanında ilk defa bu çalışmada kullanılmış olması ile alanda bu türden girişimlere ön ayak olmak çalışmamızın temel motivasyon kaynağını oluşturmaktadır. Çalışma izleyen satırlarda yazıldığı şekilde yapılandırılmıştır. Çalışmada önce modern dönem ile birlikte gözetimin değişen doğası teknolojik gelişmeler bağlamında yeniden ele alınarak panoptik model detayları ile birlikte açıklanmıştır. Ardından panoptik modele yöneltilen eleştirilere yer verilmiştir. Çalışmanın ilerleyen sayfalarında panoptik gözetim ve izlenen davranışı arasındaki ilişki Bentham/Foucault'un görüşlerine dayanılarak değerlendirilmiş olup söz konusu ilişkide caydırıcı etki kavramının önemine dikkat çekilmeye çalışılmıştır. Modern dönemde sağlık hizmetleri ve sağlık çalışanlarının önemi aktarıldıktan sonra sağlık çalışanları arasında panoptik korku ve davranış geliştirme konusu sağlık hizmetleri alanında yaşanan gelişmeler ve varsayımsal olaylar 1şı ğında değerlendirilmiştir. Çalışma literatürde yer alan farklı görüşler ve sağlık hizmetleri alanında son dönemde yaşanan gelişmelerin panoptikonik eğilimi tartışılarak tamamlanmıştır.

\section{MODERN DÖNEM, GÖZETIM VE PANOPTIKON}

Sanayi devrimi ile birlikte ortaya çıkan yeni çalışma biçimleri ve rasyonalizasyon arayışları büyük ölçüde kas gücüne dayandığından emeği odak noktası olarak kabul etmiş ve işçileri sıkı bir denetim mekanizması ile sürekli olarak kontrol etme amacı gütmüştür. Max Weber' in çalışmaları ile hayatımıza giren "rasyonalizasyon" kavramı bu dönemin en önemli kavramlarından biri haline gelmiştir (Shortell \& Kaluzny, 2006). Benzer şekilde 1900'lü yılların başında ortaya çıkan yönetimi bilimselleştirme arayışı ve bu kapsamda F. Winslow Taylor'un Bilimsel Yönetim Yaklaşımı ile Henri Fayol'un Yönetim Süreci yaklaşımı çalışanların davranışlarını bilimsel esaslara dayandırarak rasyonelleştirmeyi hedeflemiştir. Çalışmaların odak noktasında iş sahiplerinin çıkarlarını olabildiğince arttırmak gelmiştir. $\mathrm{Bu}$ amaçla geliştirilen veya üretilen model ve yaklaşımlarda genellikle emek bu gayeye hizmet edecek bir araç olarak görülmüştür. Üretim örgütlerinde sermayeyi maksimize etmeye yönelik bu kuramsal ve pratik çalışmalarda hedefe ulașmanın yollarından biri Charli Chaplin'in "Modern Zamanlar" filminde mizahi bir şekilde gösterdiği gibi işçilerin sıkı ve sürekli bir şekilde denetlenmesinden geçmiştir. Çalışmanın her anının başka bir ifade ile gerek çalışanların ürettikleri üretim miktarı gerekse çalışma biçimleri ile davranışlarının sürekli olarak izlenmesinin ana hedefi, çalışanların işletmenin karlılığına azami düzeyde katkı koymalarını sağlatmaktır, bu hedef gözetlemenin en temel amacını oluşturmuştur.

Modern dönemle birlikte denetim işlevi organizasyonlardan hayatın içerisine girmeye başlamıştır. Modern yaşam, kamusal ve iş alanlarında günlük yaşamın hemen hemen her anının gözetlendiği ve sosyal olayların takip edildiğine şahitlik etmektedir. Hayatın hemen hemen her anında ve her yerinde göz kırpmayan elektronik gözler (kameralar) bulunmaktadır ve bu gözlerle sosyal yaşam içerisinde etkileşimde 
bulunan insanlar sürekli olarak izlenmektedir. Yatılı okullar, askeri kışlalar, hapishaneler, hastaneler gibi kurumlar sakinlerini gece gündüz gözetim altında tutarlar ve kurallardan herhangi bir sapma hızlı bir şekilde saptanır ve çözüm geliştirilmesi yoluna gidilir (Bauman, 2018a, 2018b).

Bir olgu olarak gözetim yıllardır sessizce artmakta ve modern dünyanın temel karakteristiklerinden biri haline gelmiş durumdadır. Bauman'ın çalışmalarında üzerinde dikkatli durduğu ve sürekli olarak ileri sürdüğü üzere panoptik-sonrası akışkan modern dünyada yaşıyoruz (Bauman \& Lyon, 2018). Bir başka çalışmasında Bauman (2018b), bu dünyayı pragmatizmin en yüksek rasyonellik olduğu bir dünya olarak tanımlamaktadır. Alman Sosyolog Ulrich Beck ise modern dönem ile birlikte oluşan nihai yapıyı "risk toplumu" olarak ifade etmektedir (Beck, 1992). Bauman ve Lyon (2018), modernite kavramı ile kastedilenin, her şeyin değiştiği veya "akışkan” bir niteliğe sahip olduğu ve modernitenin birtakım yeni ve değişik yollarla akışkanlaşması olarak ifade etmektedirler. $\mathrm{Bu}$ durum elbette ki gözetim için de söylenebilir. Zira gözetim eskiden büyük ölçüde fiziksel olarak yapılırken bugün söz konusu eylem daha esnek ve devingen bir hal almıştır (Bauman \& Lyon, 2018). Burada teknoloji ve ağ bağlantılarının gelişimi ile yaşanan devrimin iş ve sosyal yaşamı dönüştürücü etkileri göz ardı edilemez niteliktedir. Teknoloji baş döndürücü hızla değişmekte ve gelişmektedir ve sosyal yaşam git gide çevrimdışı olmaktan çevrimiçi olmaya doğru yönelim göstermektedir.

Michel Foucault, 20. yüzyılın en etkili filozoflarından biridir ve ileri sürdügü görüşler günümüzde halen - her ne kadar bilim insanları arasında tam bir uzlaşı olmasa da - geçerliliğini korumaktadır. Çok farklı alanlarda kitaplar kaleme alan Foucault, günümüze en temel eserler arasında yer alan yapıtlar bırakmıştır. Foucault, Jeremy Bentham'in "panoptikon" adlı hapishane modelini kendi kitabında günümüz “modern gözetimi”ni ifade etmek üzere bir metafor olarak kullanmıştır (Foucault, 1979). Jeremy Bentham ise bu modeli geliştirmede kendisinden daha genç olan erkek kardeşinden esinlenmiştir. Bentham'ın kardeşi ise Paris'te bir askeri okulda bulunduğu dönemde böylesine bir yapının farkına varmıştır (Manokha, 2018). Foucault (1979), okulun panoptik bir anlayışla yönetilmesinde öğrencilerin cinsel davranışlarını - özellikle de eşcinsellerin - etkin bir şekilde yönetme amacının ağır bastığını ifade etmiştir.

Panoptikon modeli, yuvarlak bir şekle sahip olan tam ortada bir kule bulunan bir yapıdır ve bu kulenin içerisinde izleyici yer almaktadır. Modelin yapısı öyle bir şekilde tasarlanmış ki kule içerisinde bulunan izleyici, kişilerin bulunduğu tüm hücreleri hücreye yansıyan 1 şı aracılığıyla sürekli olarak izleyebilmektedir. Buna karşın, kişiler hücreye gelen 1ş1ktan dolayı kulede bir izleyici bulunup bulunmadığını bilme imkânına sahip değildir. Bu nedenle kişiler kulede hep bir izleyici varmış gibi davranış gösterirler ve geliştirdikleri bu davranışı ise belli bir zaman sonra içselleştirirler (Foucault, 1979). Aslında bu model psikolojik bir tasarımı tasvir etmektedir. Ne var ki kulede çoğu zaman izleyici yoktur, kişiler yine de izleniyor oldukları algısına kapılmaktadır ve doğal olmayan davranışlar sergilemektedir. Eckermann'ın (1997) belirttiği üzere, sürekli gözetim altında olmanın doğal bir sonucu olarak kişilerde öz-gözetim ve öz-disiplin teşvik edilmektedir. Böylece sosyal kontrolün pratik bir metodu kolaylıkla kullanılmış olur.

Yönetim disiplini içerisinde önemli bir düşünür olarak görülen Henry Mintzberg'e bu konuyla ilgili olarak başvurmakta yarar bulunmaktadır. Mintzberg'e göre örgüt, biçimsel bir otorite sistemidir. Örgütün nasıl yapılanması gerektiği ile ilgili olarak geliştirdiği modelde, "strategic apex" diye nitelendirdiği birim tepe yönetimidir ve azınlık grubunu oluşturmaktadır. En altta ise "merkezi hizmet üretim birimi" olarak ifade ettiği operasyonel faaliyetleri yürüten çalışanlar (profesyoneller ve diğerleri) bulunmaktadır. $\mathrm{Bu}$ modelde gözetim ve denetim faaliyetleri orta kademe yöneticileri kullanılarak yerine getirilir (Mintzberg, 2014). Bu model ile açıklanmaya çalışılan husus, yönetimin olduğu her yerde gözetim ve denetim olgularının varlığından kolaylıkla söz edilebileceğidir.

\subsection{Teknoloji - Panoptikon İlişkisi}

Gözetim sosyal yaşamda her zaman var olmuştur ve merkezi bürokratik yapıların artışı ile birlikte gelişimini sürdürmüştür. Bir etnografik çalışmada (Westin, 1967), en ilkel toplumlarda dâhi gözetim mekanizmalarının farklı tiplerinin bulunduğu ileri sürülmüştür. 1980'lerde bilgisayarın gelişimi ile birlikte gözetim olgusu önemli ölçüde ivme kazanmıştır. Alvin Toffler'in "üçüncü dalga" adlı kitabı bilgi teknolojisinin toplum üzerinde nasıl etkiler yarattığını açıkça ortaya koymaktadır (Toffler, 2008). Gözetime esas oluşturan verinin temin edilmesi, kaydedilmesi ve depolanmas1, veriler arasında bağlantıların oluşturulması ve gerektiğinde kullanılması gözetim mekanizması ile ilgili yaşanan paradigmatik değişimi gözler önüne sermektedir. $\mathrm{Bu}$ nedenle de gözetim alanında çalışan bazı analistler tarafından gözetimin akışkan bir nitelik kazandığı dile getirilmektedir (Bauman \& Lyon, 2018). Gözetim, kişilerin verileri kullanılarak gerçekleştirilen bir faaliyet olduğundan verilerin gizlilik ve güvenliği ile ilgili endişeler ortaya 
çıkabilmektedir. Bu konuya paralel olarak yapılan bir çalışmada (Van Haute, Roets, Alasuutari \& Vandenbroeck, 2018), kişilerin yoksulluk durumları ile ilgili özel bilgilerin organizasyonlar-arası ağlarda çocuk yoksulluğu ile mücadelede nasıl kullanıldığ Foucault'çu bir yaklaşım benimsenerek panoptik gözlerle incelenmesi gerektiği raporlanmıştır.

Otorite veya devlet, modern öncesi dönemde suç işleyen kişileri katı bir şekilde cezalandırma yoluna gitmiştir. Modern dönemle birlikte devletin suç işleyen kişileri cezalandırmada kullandığ yöntem(ler)de değişim ve dönüşümler yaşanmıştır. Modern gözetim kavramı, bu durumun en açık örneği niteliğindedir. Kanımızca sistem içerisinde kişileri kontrol etme amaçlı tasarlanan ve kullanılan her türlü teknoloji modern gözetim kapsamında değerlendirilebilir. Modernite ve Holocaust adlı eserinde Bauman (2007), bilgisayar destekli gözetim aracılığı ile mesafe, uzaklaşma ve otomasyon fonksiyonlarının kendi üzerine düşen rolleri yerine getirdiklerini ifade etmektedir.

Panoptikon, 20. yy içerisinde büyük ölçüde modern devletin toplumsal kontrol arac1 olarak değerlendirilmesine karşın günümüzde çok farklı bağlamlarda değerlendirilmektedir. Pazarlama/tüketim amaçlı kullanım ve nüfusun belli dilimlere ayrılması ile müşteri davranışlarının anlaşılması ve bunun sonucunda müşterilere uygun mal ya da hizmetin sunulması panoptik yönelimin amaçları içerisinde yer almaktadır. Harvard'da bir öğrenci iken geliştirilen ve sahibi Mark Zuckerberg'i milyoner yapan sosyal paylaşım ağı Facebook günümüzde modern gözetimi anlatmada kullanılan en temel ağların başında gelmektedir. Dünya üzerinde milyonlarca insanın en az bir hesabı bulunmakta olup bu kullanıcılar ağın içerisinde çeşitli yollarla etkileşimlerde bulunmaktadırlar. Kullanıcıların ağ üzerinden etkileşimleri, tercihleri, yaptığı sörfler veri tabanlarında sürekli olarak kaydedilmektedir ve potansiyel bir pazarlama aracı olarak aktif bir şekilde kullanılmaktadır (Bauman \& Lyon, 2018). Bauman ve Lyon'a (2018) göre, tüketim toplumunda yaşıyoruz ve tüketiciler kendin-yap anlayıșı ile kapitalist sistem içerisinde yeniden metalaştırılmaktadır. Yani tüketiciler "satılabilir mal" statüsüne yükseltilmektedir.

Bir gözetim aracı olarak değerlendirilebilecek Facebook, sadece insanlardan bilgi toplamakla kalmamakta, aynı zamanda arkadaşlıklar yoluyla temel sınıflandırmaları da çok başarılı bir şekilde yapabilmektedir. Şevkle ve bağımlı bir şekilde insanların bu teknolojiyi nasıl kullandıklarının yanı sira insanların bu teknoloji tarafindan nasil kullanılabileceği bu perspektifle daha iyi değerlendirilebilir (Bauman \& Lyon, 2018). Buna ek olarak, teknolojinin hayatımızı kolaylaştırmasının yanı sıra çoğu özgürlügüumüzü bunların başında ifade özgürlüğü gelmektedir kısıtladığının altını çizmek gerekmektedir. Sosyal ilişki ve etkileşimlerimizi sürdürmemiz pahasına teknoloji kullanımı ile bıraktığımız izler çeşitli otoritelerce gözetlenmekte olup çok çeşitli amaçlarla kullanılmaktadır. Bu durumun çevrimiçi hayatlarımızı önemli ölçüde etkilemesi son derece kabul edilebilirdir zira çeşitli otoritelerce gözetildiğinin farkında olan biri sosyal ağlar üzerinden yaptığı paylaşımlara dikkat eder ve gelecekte kendisini sıkıntıya sokabilecek her türlü davranışı sergilemekten kaçınma eğilimi gösterir. Bunun da ötesinde, çevrimdışı hayatlar da bu durumdan payını almaktadır. Kişiler sosyal yaşamları içerisinde de yoğun teknoloji kullanımı nedeniyle sürekli gözetim altında olduğu hissini yaşayabilmekte ve bu yaşamda sergilemiş olduğu davranışlarının bir gün çevrimiçi yaşamda yer alabileceği korkusu ile kendi davranışlarını sürekli olarak kontrol etme ihtiyacı hissedebilmektedir. Günümüzde yaygın olarak kullanılan güvenlik kameraları yaşamın hemen her yanını 24 saat gözetleyip, denetlemekte hatta kişilerde bir öz denetim sağlamaktadır. Güvenlik kameralarının kişilerde oluşturduğu öz denetim, panoptikon modelindeki denetime benzemektedir. Fakat panoptikon denetimde gözetlenen gözetleyeni görmeden denetimi kabul ederken, güvenlik kameraları marifeti ile sağlanan denetimde gözetlenen, gözetleyeni (kameraları) görerek denetim alanı içinde hareket etmek durumunda kalmaktadır. Diğer taraftan her ikisinde de esas gözetleme yerinde kimin yer aldığının bir önemi olmaksızın denetim sağlanmaktadır. Genel olarak değerlendirildiğinde, teknolojinin gözetim faaliyeti üzerinde çok derin etkileri olduğu kolaylıkla ileri sürülebilir.

\subsection{Panoptikon Modeline Yönelik Eleștiriler}

Foucault'un (1979) panoptikon metaforu, modern gözetimi açıklamak için son derece önemlidir. Buna karşın, özellikle günümüzün iletişim ve ağ teknolojilerinin gelişimi ile birlikte modern kitle iletişim araçlarının kullanılması panoptikon kavramının modern gözetimi ifade etmede yetersiz kaldığını, bunun yerine sinoptikonik ve polioptikonik bir gözetim anlayışının varlığından söz edilebilecek bir dönemde olduğu görüşü kabul görmektedir (Bauman \& Lyon, 2018; Mathiesen, 1997). Sinoptikon tarzı bir gözetimde, "azınlık çoğunluğu" değil, aksine "çoğunluk azınlığı" izlemektedir. Örnek olarak, kamusal alanda sigara içme davranışı her ne kadar kamu tarafından çeşitli mekanizmalar kullanılarak kısıtlanmaya çalışılsa da sigara birakmada en etkili yol, bireylerin toplum 
içerisinde sigara içenlere karşı dışlama davranışı içerisine girmeleridir. $\mathrm{Bu}$ amaçla benimsenen psikolojik baskı, dışlama davranışı ve eleştiriler çoğunluğun azınlık üzerinde tutum ve davranışlarını normalize etmede gözetim mekanizmasının ne derece etkili olduğunu göstermektedir. Ayrıca kamu sağlığını iyileştirme ve geliştirme ile ilgili olarak çeşitli formatlarda yayınlanan bilgiler kişiler üzerinde etkiler oluşturabilmekte ve bu kişilerde davranış değişikliği oluşturulabilmektedir (Couch, Han, Robinson \& Komesaroff, 2015). Dolayisiyla da panoptik gözetimden sinoptik tarzı bir gözetime doğru yaşanan evrim, gözetimin daha esnek ve devingen bir hale gelmesini sağlamıştır. Bauman (2017a), modern gözetimi tasvir etmede kullanılan panoptikon modelinin her ne kadar kontrol amaçlı kullanılıp istenilen sonuçları elde etse de bu tür yapıların oluşturulması ve sürdürülmesinin zor olduğu, panoptikonun ağır, hantal gözlem ve gözetleme donanımlarına artık ihtiyaç bulunmadığına işaret etmektedir. Mathiesen (1997), kaleme aldığ 1 çalışmasında Bentham ve Foucault'un panoptikon metaforunun günümüz iktidarının işleyişini açıklamakta yetersiz kaldığını, bunun yerine sinoptikon tarzı bir dünyaya geçildiğini ve rollerin değişerek azınlığın çoğunluk tarafından izlendiğini ileri sürmüştür. Foucault'çu yaklaşımda azınlığın çoğunluğu izlemesi söz konusu iken Mathiesen (1997) ise işin içerisine kitle iletişim araçlarını da dâhil ederek çoğunluğun azınlığı izlediğini ileri sürmektedir. İnsanlar bugünlerde zorlama ve baskı ile değil, disiplin sağlayıcı işlevi ön planda olan çeşitli ikna yöntemleri ile kontrol edilmektedir (Bauman, 2017a). Genel olarak değerlendirmek gerekirse, modern gözetim alanında Foucault'dan sonra yapılan bazı çalışmalar (Bauman \& Lyon, 2018; Haggerty \& Ericson, 2000; Lianos, 2003; Manokha, 2018) panoptikon metaforunun yaşanan gelişmeleri karşılamakta yetersiz kalmasından ötürü post-Foucauldist gözetim teorilerine ihtiyaç duyulduğu yönünde bir uzlaşı içerisindedirler.

Günümüzde kontrol ve özellikle toplumsal kontrol, Bentham/Foucault'un panoptikon modelinde olduğu gibi sadece belli duvarlar arasında geçerli bir olgu olmayıp toplumsal yaşamı kuşatan ve insanın günlük pratiklerinin hemen hemen hepsini kapsayan modern çağda akışkan bir hal almıştır. Dolayısıyla da bu noktada geleneksel anlayış̧a benimsenen gözetim olgusu artık akışkan gözetim olarak ifade edilmektedir zira modern gözetim belli kalıplar içerisine sokulamaz nitelikte olup iletişim ve bilgi teknolojilerinin gelişimiyle birlikte farklı niteliklere bürünmüştür (Bauman \& Lyon, 2018). En nihayetinde yaşanan tüm bu değişim ve gelişimler gözetim ile ilgili paradigmatik durumlar olarak değerlendirilebilir.

\subsection{Panoptikon'un İzlenen/Gözlenen Davranış Üzerindeki Caydırıı Etkisi}

Bir ropörtajında Zygmunt Bauman, akışkan modern dönemde belirsizliğin insan hayatında önemli hale getirdiği "özgürlük" ve "güvenlik" kavramlarından bahsederek belirsizliğin hüküm sürdüğü günümüzde insanların artık modern bir korkuya sahip olduğunu ifade etmiş ve buna "akışkan korku" adını vermiştir. Yazarın deyimiyle, akışkan korkular sürekli olarak akışkan moderniteye eşlik etmektedir. İnsanlar akışkan korkularını bir nebze de olsa azaltmak için güvenliklerini garanti altına almak amaciyla birtakım özgürlüklerinden kolaylıkla vazgeçebilmektedirler ${ }^{d}$. Dolayısıyla günümüzde insanlar söz konusu korkularını hafifletmek veya gidermek amaciyla idari aygitın kendi özgürlüklerini kısıtlayıcı birtakım uygulamalar Bauman (2018b) bu durumu, Isaiah Berlin'den alıntıladığ1 "negatif anlamda özgür" şeklindeki dikotomi ile ifade etmektedir - sergilemesine riza göstermiştir. Bu uygulamaların başında şüphesiz ki idari aygıtın kontrol aracı olarak kullandığı gözetim faaliyeti gelmektedir.

Michel Foucault'un 1977 tarihli "Disiplin ve Ceza" adlı kitabı gözetim ile ilgili çalışmalarda son derece önemli bir dönüm noktası niteliğindedire . Panoptikon, daha önce de belirtildiği üzere, modern gözetimi nitelendiren bir metafordur (Foucault, 1979). Kavramın etimolojik yapısı incelendiğinde, Yunanca "pan" ve "optikon" kelimelerinden türetilmiş olup "her yeri gören yer" anlamına gelmektedirf (Bauman \& Lyon, 2018). Foucault bu kavramı Bentham'dan ödünç alırken Bentham ise kardeşinden esinlenmektedir. Bentham'ın kardeşinden esinlenerek geliştirdiği panoptik uygulamanın 18. yy'da askeri okullarda ve hastanelerde kullanıldığı ile ilgili görüşler bulunmaktadır. Yaygın uygulamaya adını veren kişi faydacı filozof Bentham olmuştur (Foucault, 1980; Manokha, 2018). Bentham (1748-1832), "en çok sayıda kişiye en yüksek düzeyde mutluluk" sözü ile toplum için faydalı olan şeylerin yapılması gerektiğini vurgulayarak faydacı kimliğiyle öne çıkmaktadır̃ . İngiliz düşünür, en yüce değerin "çoğunluğun mutluluğu" olduğunu belirterek devletin, piyasanın ve bilimsel camianın varlı̆̆ının kayda değer tek amacının küresel mutluluğu artırmak olması gerektiğini savunmuştur (Harari,

\footnotetext{
${ }^{d}$ Zygmunt Bauman ile yapılan ropörtajdan elde edilen bilgilere https://www.youtube.com/watch?v=5_j2jstuzg0 adlı internet adresi kullanılarak erişilmiş̧tir.

e Orijinal adı "Surveiller et Punir" olan 1975 tarihli kitabın İngilizce çevirisi 1977 yılında basılmıştır.

f Panoptikon metaforu ünlü İngiliz hukuk kuramcısı ve aynı zamanda bir hapishane reformcusu olan Jeremy Bentham'dan gelmiştir.

g AnaBritannica Genel Kültür Ansiklopedisi Cilt 14, liberalizm, s. 455 .
} 
2016). Bentham'1n modeli, gözetenin her yerde birden bulunması, gözetilen nesnelerin küresel görülebilirliği ve izlenen tarafından sürekli gözlem olmak üzere üç temel varsayım üzerine şekillenmiştir (Manokha, 2018). Bu model kişilerin davranışlarının normlara ve otoritenin beklentilerine uygunluğunu sağlamak üzere normalize edilmesi gerektiğini ortaya koymaktadır (Johnson \& Regan, 2014). Faydaci model perspektifi ile durum değerlendirildiğinde, Bentham'a ilham veren şey faydacı bir toplum inşa etmektir. Bu proje, kişileri cezalandırmanın en maliyet-etkili modelini ortaya koymaktan ileri gelmektedir. Bentham'a göre panoptikon modeli, insanların gözetiminde, disipline edilmesinde ve normalize edilmiş davranışların geliştirilmesinde maliyet-etkili bir çözümdür zira kişileri gözetleyen çok fazla insana ihtiyacınız yoktur (Bentham, 1995). Cezalandırma ile ilgili faydacı yaklaşımında Bentham (1995), "Kolomb'un Yumurtası"nı keşfettiğine inanmaktadır ${ }^{\mathrm{h}}$. Foucault bu durumun gelişen kapitalist endüstri toplumu ile yakından ilişkili olduğunu ileri sürmektedir. Hapishaneler, iş yerleri, fabrikalar, askeri kışlalar ve okulların artan kapitalist toplumun ve burjuvazinin ihtiyaçlarını karşılamak için yeni disiplin biçimlerini yaratmak amaçlı olduğunu ileri sürmüştür (Foucault, 1980). Bauman (2018b) ise bu durumun kapitalist dönemde neoliberal girişimci yurttaş idealinin yüceltilmesi ile yakından ilişkili olduğunu ve bir bireysellik pratiği olarak değerlendirilmesi gerektiğini savunmuştur. Coase'un (1937) kaleme aldığı yazı bu durumu doğrular niteliktedir zira söz konusu yazısında firmanın doğası ile ilgili çok önemli saptamalarda bulunarak firmanın varlığını işlem maliyetlerini minimize etmenin aracı olarak değerlendirmiş olup ilerleyen dönemlerde bu görüş başka yazarlar tarafindan da benimsenmiştir (Williamson, 1975).

Bentham (1995), insan davranış(lar)ının normalize edilmesinde baskı ve güç yerine gözetim mekanizmasının gerekliliğini vurgulamaktadır. $\mathrm{Bu}$ gözetim mekanizması kullanılarak kişilerin tanınabilirliği sağlanmalıdır. Gözetim olgusunu sadece panoptik organizasyonda değil hayatın her alanına yaygınlaştırma hedefi Bentham'ın hayalini oluşturmaktadır. $\mathrm{Bu}$ yönüyle Bentham kanımızca geliştirilen gözetim teknolojilerinin öncülerinden biri olarak değerlendirilebilir. Bugün gelinen noktada, gözetim teknolojilerinin gelişimi ile ilgili epeyce yol kat edildiğini söylemek mümkündür. Yüz tanıma sistemleri, parmak izi kullanımı,

\footnotetext{
h Cumhuriyet Gazetesi'nde kaleme aldığı yazısında Emre Kongar, "Kolomb'un Yumurtası" kavramı ile ilgili, "Bir sorunun çözümü için, mevcut koşullardan ve koşullanmalardan kurtulmak, bazen de, sorunun ve çevrenin koşulların değiştirmek gerektiğini gösterir" ve "bir çözümdeki basitlik ve kolaylıktan çok zekâyı işaret eder" şeklinde açıklamalar yapmıștır. Erișim Tarihi: 1.12.2018
}

biyometrik göstergeler vb. gelişmeler bu teknolojilerde yaşanan ilerlemeleri açıkça göstermektedir. Dolayısıyla da Bentham'ın hayalinin gerçekleştirilmesi yönünde önemli ölçüde gelişmeler yaşandığını söylemek yanlış olmayacaktır.

Foucault (1979), küresel saltanatın normatif tabanlı olduğunu ileri sürerek öğretmen-yargıç, doktoryargıç, eğitici-yargıç ve işçi-yargıç bir toplumda yaşadığımızı ifade etmiştir. Bu tür bir bilgi/güç konfigürasyonu, izlenenlerin normlara ve izleyicilerin beklentileri yönünde herhangi bir güç veya baskı kullanılmadan normal davranışlar sergilemesine olanak sağlamaktadır ve Foucault bu durumu öz teknolojiler (technologies of the self) olarak adlandırmaktadır. Foucault'çu yaklaşımda panoptikon, panoptik disiplin veya ruh eğitimini ön planda tutar. Bir başka anlatımla ifade etmek gerekirse, modern gözetim kişilerin disipline edilmesinde kıymetli bir araç olarak değerlendirilmiştir. Foucault'a göre disiplin, davranış1 ve motivasyonu değiştirmek için ruhu kontrol etmeye yarayan temel bir anahtar niteliğindedir (Foucault, 1979). Thaler ve Sunstein (2017) ise beklentilere paralel davranışları oluşturmak için dürtme mekanizmasının önemine değinmektedir. Sözü edilen dürtme mekanizması panoptik rejim altında uygulanan bir faaliyet olarak değerlendirilebilir.

Gözetim olgusu ile ilgili değinmekte fayda gördüğümüz bir kavram soğutma/caydırıcı etki (chilling effect) olarak adlandirılan ve Edward Snowden'ın çalışmalarında yer edinen kavramdıri. $\mathrm{Bu}$ etki, gözetim altında olduğunu bilen kişilerin izleyenin norm ve beklentilerine uygun davranışlar sergileyeceğini ifade etmektedir (Manokha, 2018). Bu etki, neo-klasik dönemde insani ilişkiler hareketi öncülerinin - Elton Mayo ve arkadaşları - elde ettiği bulgularla paralellik göstermektedir. Hawthorne araştırmaları kapsamında yapılan deneylerde gözetim altında olduğunu bilen kişiler istenen yönde davranışlar geliştirmiştir. Sözü edilen bu durum "Hawthorne Etkisi" olarak adlandırılmıştır (Koçel, 2015). Snowden'ın caydırıcı etki ile ilgili çalışmalarından sonra yapılan çok sayıda çalışmada gözetim altında olduğunun farkına varan kişilerin davranışlarında çarpıcı değişimler yaşandığ gözlenmiştir (Lashmar, 2017; Pen American Center, 2013). Buna paralel olarak, sosyal psikoloji ve son yıllarda giderek artan bir şekilde deneysel iktisat ${ }^{j}$

${ }^{i}$ Gerçek bir olaydan ilham alınarak hazırlanan Snowden filmi, Amerika Birleşik Devletleri kaynaklı küresel gözetimin iç yüzünü medyaya yapılan ifşa aracılığıyla açık bir şekilde ortaya koymaktadır.

j Deneysel iktisat, son yıllarda oldukça popüler hale gelmis bir alan olarak karşımıza çıkmaktadır. George Akerlof, 2001 yılında Nobel Ekonomi Ödülü'ne layık görülerek bu ödül, Michael Spence ve Joseph E. Stiglitz ile aralarında paylaştırılmıștır. Bu 
alanında yapılan araştırmalar, kişilerin davranışlarının, diğer insanların onların kim oldukları hakkındaki düşüncelerine bağlı olduğunu göstermiştir (Akerlof \& Kranton, 2016). Bu duruma sonradan her ne kadar ifade özgürlüğünü kısıtladığı yönünde eleştiriler gelse de batılı demokratik ülkelerde yaşayan insanlar, iletişim ve sosyal ağların yaygın kullanımı ile birlikte çevirim-içi ve çevirim-dışı hayatlarında sürekli olarak gözetlendiklerinin farkındadırlar. Foucault'un (1979) perspektifi ile durum değerlendirildiğinde, gözetimin caydırıcı etkisi sürpriz bir gelişme değildir zira Foucault, kişilerin gözetim altında tutulmasının onları disipline ettiğini ve kendiliğinden normal davranışlar sergileyeceğini savunmuştur.

\section{MODERN DÖNEMDE SAĞLIK HİZMETLERİ VE SAĞLIK ÇALIŞANLARI}

18. yy'dan itibaren tıpta ve sağlık hizmetlerinde modern bir dönüşümün yaşandığı ifade edilebilir. Yaşanan bu dönüşüm şüphesiz ki salt bir faktör ile anlatılamayacak kadar karmaşıktır. Birtakım görüşler tıpta yaşanan bu atılımın teknoloji eksenli olduğu yönündeyken bazı görüşler ise hekimlerin tedavi ağırlıklı sağlık hizmeti sunmaya başlamalarından ileri geldiği yönündedir. Hekimlerin 18. yy'dan itibaren hastalığa karşı bilgi dağarcıklarının gelişmesi ile birlikte kavrayışlarının da gittikçe artış göstermesi, farklı endüstrilerde geliştirilen teknolojilerin tıp sektöründe kullanılmaya başlanması ile tıpta modern dönem başlamıştır. Anlaşıldığı üzere, tıbbın hastalık ve ölümlere bakış açısı zamanla değişim göstermiştir. $\mathrm{Bu}$ durumda Fransız İhtilali sonrasinda kadavralar üzerinde detaylı inceleme yapma imkânı elde eden hekimlerin anlayış ve kavrayışlarında ortaya çıkan ilerlemeden dahi söz edilmektedir (Ulutaş, 2002).

Michel Foucault, kaleme aldığı "Kliniğgin Doğuşu" adlı kitabında modern dönemle birlikte sağlık hizmetlerinin artık hastane organizasyonu çatısı altında sunulmaya başladığını ileri sürmüştür (Foucault, 2002). Modern sağlik hizmetleri günümüzde büyük yapılar içerisinde sunulmaktadır. Büyük bloklar halinde yapılan sağlık kurum ve kuruluşlarında yapı, teknoloji ve insan güvenliğinin sağlanması için bina çevresinde ve içinde gözetim mekanizmasından önemli ölçüde yararlanılmaktadır. Hasta ve sağlık profesyoneli hareketliliğinin en fazla olduğu koridorlarda ve hasta bekleme salonlarında kameralar etkin bir

alanda öne çıkan bir başka isim Richard Thaler, 2017 yılında Nobel Ekonomi Ödülü'ne layık görülmüştür. Ekonomiyi ekonomi yapan şeyin bireyin davranışları olduğu gerçeği göz önünde bulundurulduğunda, söz konusu ödüllerin bu kişilere gitmesinin neden ve önemi daha iyi anlaşılabilir. şekilde kullanılmaktadır. Söz konusu kameralar bir gözetim aygıtı olarak değerlendirilebilir.

Sağlık çalışanlarının kendilerini hastane içerisinde güvende hissetmeleri elbette ki son derece önemlidir. Buna yönelik olarak yapılan bir çalışmada (Ulutaş, 2002) elde edilen bulgular dikkate değerdir. Katılımcıların bazıları hastane içerisinde otomasyonun artışı ve kameraların kullanılmasını denetim ve baskı unsuru olarak algılarken, bazıları ise bu uygulamaların çalışan güvenliği açısından gerekli ve önemli olduğunu ifade etmişlerdir. Hastane içerisinde kameralardan yararlanılması bazı çalışanlar için giriş/çıkış saatlerinin izlenimi hususu nedeniyle denetim baskı mekanizması olarak algılanırken gece vardiyasında nöbet tutan bir doktor veya hemşire için can güvenliği veya iş güvenliği olarak algilanabilmektedir.

Günümüze doğru gelindiğinde, sağlık hizmetlerinin eskiye nazaran çok daha modern bir tarzda, ileri teknoloji kullanılarak sunulduğu ifade edilebilir. Tıbbın farklı alanlarında yaşanan gelişmeler ile birlikte tanı ve tedavi süreçlerinde uygulanmak üzere daha etkin tedavi yöntemleri kullanılmaktadır. Kanımızca sağlık hizmetlerinin bu özelliğini hizmetin kendi doğasına uygun "akışkan"” kavramı ile ifade etmekte fayda bulunmaktadır. Sağlık hizmetlerinin akışkan olmasında profesyonellerin rolü son derece önemlidir. Dünya Sağlık Örgütü (DSÖ) 2009 yılında ilan ettiği raporda, sağlık çalışanlarını sağlık sisteminin temel yapı taşlarından biri olarak değerlendirmiştir ve sistemin güçlendirilmesinde çalışanların güçlenmesinin de önemli olduğunu vurgulamıştır (WHO, 2009). Sağlık hizmetleri, bir ülkenin kalkınmasında üretim gücünü garanti etme yeteneğinden ötürü son derece önemsenmektedir. Son yillarda konuyla ilgili yazınsal birikim insanların sağlık statüsünün topyekûn olarak iyileştirilmeden kalkınma hedeflerinin başarılmayacağını ortaya koymaktadır. Milenyum Kalkınma Hedefleri'nde bu durum çok açık bir şekilde görülebilmektedir zira bu hedeflerin çoğunluğu insan sağlı̆̆ koruyucu ve tedavi edici hizmetlerin varlığını gerektirmektedir (Todaro \& Smith, 2012; Kidak \& Demir, 2018). $\mathrm{Bu}$ nedenledir ki sağlik hizmetlerindeki aktörlerin (hekim, hemşire, ebe, teknisyen vb.) - toplum üzerinde iyileştirici etkileri bulunan profesyoneller - yönetimi söz konusu olduğunda azami ölçüde hassasiyet gösterilmesi gerekmektedir.

\footnotetext{
k Zygmunt Bauman "Akışkan Modernite" ve "Akışkan Gözetim” adlı kitaplarında "akışkan" kavramını kapsamlı olarak açıklamaktadır. Biz de bu çalışmada kendine özgü yapısından ötürü sağlık hizmetlerini "akışkan" olarak ifade etmekte yarar görüyoruz.
} 


\subsection{Sağlık Çalışanları Arasında Korku ile İlgili Yazın ve Panoptik Korku}

Gözetim olgusunun gelişiminde Sanayi Devrimi sürecinde yaşanan gelişmelerin itici güç oluşturduğu söylenebilir. Bu dönemle birlikte işçiler büyük fabrikalarda sürekli olarak gözetim altında tutulmuş olup fabrika alanının her tarafı yöneticiler tarafından çeşitli araçlarla sürekli olarak izlenmiştir. Charlie Chaplin'in başrolünü oynadığı 1936 yapımı "Modern Zamanlar" filmi yaşanan bu gerçekleri gözler önüne sermede önemli bir örnektir. Kaytarma amaçlı davranış sergilendiğini anında fark eden yönetici, kamera ve sesli sistem ile Chaplin'in işinin başına dönmesini gerektiği yönünde onu çok sert bir şekilde uyarır. Söz konusu filmdeki gözetim kültürü klasik yönetim akımının ileri sürdüğü ilkelerden bağımsız değildir. Evrensel ilkeler ortaya koyduklarını ileri süren klasikçiler, insanların tembel olduğunu ve kaytarma yönünde davranış gösterdiklerini ifade etmişlerdir. ${ }^{1}$ Dolayısıyla da bu anlayış, çalışanların sıkı bir şekilde denetlenmesi arayışını da beraberinde getirmiştir (Ettinger, 1965; Koontz \& Weihrich, 1988). Denetim anlayıșı Max Weber'in çalışmalarında da yer edinmiştir. Bürokrasi yaklaşımı ile Weber, organizasyonun rasyonalizasyon ilkeleri ile hareket etmesi gerektiğini ileri sürmüştür (Williams, 2007). Yaşanan tüm bu gelişmeler, modern dünyanın inşasında şüphesiz katkılar sağlamıştır. Bu durumu olumlu olarak ve modernitenin, yazarın deyimiyle sürekli daha iyiye yönelik bir arayış içinde olmanın, başarılması için son derece gerekli olduğunu ileri süren Zygmunt Bauman gibi filozoflar olmasının yanı sıra, günümüzde ve gelecekte ortaya çıkacak gelişmeleri distopik düzlemde kehanet olarak değerlendiren George Orwell ve Aldous Huxley gibi distopik yazarlar da bulunmaktadır. Orwell'a göre "büyük birader" herkesi gözetlemektedir. Bu görüş günümüzde geçerliliğini korumaktadır zira devlet adı verilen otorite veya güç, insanları kişisel bilgileri aracılığıyla takip etmektedir ve gözetim mekanizması adeta modern devletin aklı haline gelmiştir. Huxley'e (2018) göre, toplum içerisinde yaşanan olaylara karşı insanlar artık duyarsız bir hale gelmiştir ve bu tür kaygısız insanların olduğu distopik bir toplumda her şey kontrol altındadır. Bauman (2018a) bu iki yazarın ileri sürdüğü görüşleri aşağıda sunulduğu şekilde analiz etmektedir.

\footnotetext{
${ }^{1}$ McGregor (1960), The Human Side of Enterprise adlı eserinde yöneticilerin çalışanlara bakışını $X$ ve $Y$ biçiminde açıklar. X yönü, çalışana karșı klasiklerin bakıșını bir bakıma karakterize eder. Buna göre çalışanlar doğuştan tembel, iş yapmayı sevmeyen, sorumluluk almaktan kaçınan, pasif durumda bulunan bireylerdir.
}

"Yazarların ortaya attıkları bu iki dünya tasavvuru birbirlerine taban tabana zit olmakla birlikte bireysel özgürlüklerin yok edildiği, dünyanın yöneten ve yönetilen, düzeni koyan ve düzeni takip edenler, kuralları koyan ve kuralları takip eden olarak ve bütün iplerin küçük bir seçkinler grubunun elinde bulunduğu sıkı bir şekilde kontrol edilen dünya öngörüleri olması nedeniyle de özünde bir noktada birleşmektedirler.”

Buraya kadar yapılan tartışma gözetimin geçmişten günümüze evrimi ile ilgili iyimser ve kötümser bakış açıları sağlamaktadır. Gözetim, 21. yy. içerisinde geçmişe göre önemli ölçüde farklılık göstermiştir ve karşımızda duran şey Lyon'un deyimiyle, "iktidarın elektronik bir sinyal hızında hareket ettiği” bir durum olarak tasavvur edilebilir (Bauman \& Lyon, 2018). Yaşanan bu gelişmelerle birlikte toplum içerisinde insanların en çok arayış içerisinde oldukları şey hiç şüphesiz güvenlik ihtiyacı olarak karşımıza çıkmaktadır. Bauman (2017a), sosyal yaşam alanı için önemli bir hale gelen "taciz" kavramını "modern korku" olarak değerlendirmiştir. İnsanlar toplum içerisinde herhangi bir nedenle taciz edilmeye karşı kendilerini güven içerisinde hissetmek isterler ki bu durum insanın en doğal ihtiyaçlarından biridir. Maslow'un (1954) "İhtiyaçlar Hiyerarşisi Teorisi" güven hususunu önemli ölçüde açıklamaktadır. Maslow'a (1954) göre güvenlik ihtiyac1, temel fizyolojik ihtiyaçların karşılanması ile ortaya çıkmaktadır ve bu ihtiyaç karşılanmadığı takdirde kişilerin bir sonraki adımda yer alan ihtiyaçlarını karşılaması mümkün değildir.

Güvenlik ihtiyacı her alanda olduğu gibi sağlık hizmetleri alanında da öncelikli ihtiyaçlar arasında yer almakta olup sağlık sisteminin temel yapı taşları olarak görülen sağlık çalışanları için ayrıcalıklı önem arz etmektedir. Günümüzde sağllk hizmeti sunucuları, inanılmaz bir biçimde çok sayıda hasta servisinde zaman ve kaynak kısıtı altında hizmet sunumunu gerçekleştirmek için büyük emek harcamaktadırlar. Bu kısıtların yanı sıra, çok sayıda disiplinin koordinasyonu ile en etkin ve etkili hizmet sunumu gerçekleştirilmeye çalışılmaktadır (Castel vd., 2015). Modern sağlık hizmetleri oldukça karmaşık nitelikte olmakla birlikte ileri düzeyde teknoloji eşliğinde bir ekip olarak sunulmaktadır. Sağlık hizmetlerinin karmaşık olma özelliğini ortaya çıkaran bu durumlar hizmetin maksimum ölçüde güvenle sunulmasını gerektirmektedir. Kendini güvende hisseden ve herhangi bir nedenden ötürü korku duymayan sağlık çalışanları hizmet sunumunu daha etkin ve etkili bir şekilde gerçekleştirebilir. Korku, yaşamsal hizmetler niteliğinde olduğundan sağlık hizmetleri alanı için ayrıcalıklı önem arz etmektedir. Sağlık profesyonellerinde yaşanan korku duygusu bu 
kişilerin psikolojik sağlık halleri üzerinde doğal olarak olumsuz etkiler oluşturabilmektedir. Bir hastanesinin acil servisi için sunulan varsayımsal olay üzerinden durum daha iyi anlaşılabilir. Akşam saatlerinde bir erkek hastanın göğüs ağrısı ve bulantı şikâyeti ile acil servise başvurduğu düşünülsün. Hastanın bir yıl önce sağ bacağının diyabet koplikasyonuna bağlı ampute edildiği ve söz konusu hastanın aynı zamanda hipertansiyon tedavisi gördüğü varsayılsın. Başvuru sonucunda hastaya akut miyokard infarktusu tanısının konduğu ancak kardiyoloji uzman hekimi ve yeterli donanım bulunmaması nedeniyle hastanın il merkezine sevkinin istendiği kabul edilsin. Merkezdeki hastane yataklarının dolu olması ve uzman doktorun komplike olan bu hastanın ileri derecede bir sağlık merkezine sevk edilmesinin daha yararlı olacağı yönündeki görüşü üzerine başka illerdeki sağlık kuruluşlarına başvuru yapıldığı ancak benzer yönetsel sorunlarla karşılaşılmasından ötürü hastanın sevkinin 4 saatte gerçekleşebildiği varsayılsın. Bu kritik süreçte sağlık çalışanlarının yaşayabilecekleri hastayı kaybetme korkusu, hastanın yaşamsal tehlikesine karşı yapılacak müdahaleler ve diğer hastaların en iyi ve kaliteli sağlık hizmeti alması için sarf edilecek emek, sağlık çalışanlarının önemli ölçüde stres ve korku yaşamasına neden olabilir. $\mathrm{Bu}$ süreçte hastane koşullarının yetersiz olması, gerekli donanım ve uzman doktorun bulunmaması, sağlık çalışanlarının iş verimliliği, çalışma kalitesi ve psikolojisi üzerinde olumsuz etkiler oluşturabilmektedir. Buna ek olarak, hastanın içinde bulunduğu duruma bağlı vital bulgularının stabil olmadığı ve yaşanan bu aksaklıklardan olumsuz etkilendiğine şahitlik edilebilir. Sağlık hizmeti alanında gerekli teçhizatın bulunmaması ile birlikte yaşanan her türlü aksaklık sağlık personelinin korku hissetmesine neden olabilir, bu durum ise çalışanın motivasyonu, iş doyumu, iş verimi ve hasta ve yakınları ile iletişim sürecini önemli derecede etkileyebilir.

Korku kavramı, Oxford Dictionary'de “tehlike, ağrı veya zararın tehdidinden kaynaklanan hoş olmayan bir duygu" olarak tanımlanmıştır ${ }^{\mathrm{m}}$. Buradan hareketle panoptik korku kavramı ise "bir çalışanın üstü/üstleri tarafindan sürekli olarak gözetlendiğine ilişkin algısından kaynaklanan tedirginlik veya endişe duyma hali şeklinde ortaya çıkan hoş olmayan bir duygu" olarak tanımlanabilir. Bir çalışanın panoptik korkuyu yaşayabilmesi için üstün söz konusu çalışanı sürekli olarak izlemesi (veya izlediği izlenimini uyandırması) ve çalışanın da bu durumun farkında olması gerekmektedir. Buna paralel olarak Ulutaş (2002), kaleme aldığ kitabında "klinik yönetişim" kavramından söz etmektedir. Bu kavram dikkate değerdir zira başta

\footnotetext{
${ }^{\mathrm{m}} \mathrm{Bu}$ tanıma https://en.oxforddictionaries.com/definition/fear adl internet adresi kullanılarak erișim sağlanmıștır.
}

hekimler olmak üzere sağlık profesyonellerini denetleyen, klinik özerkliğe karşı yöneticilere daha fazla yönetsel hareket alanı sağlanmaktadır. Dolayısıyla da bu tür bir yönetim tarzı, hekimlerin bütün eylemlerinin gözetlendiği veya gözetlendiği algısı yaratmak amaçlı tasavvur edilen panoptikonik bir rejim olarak değerlendirilmiştir.

Sağlık çalışanları arasında korkuyu ele alan hatırı sayılır nicelikte çalışma bulunmaktadır. Sağlık hizmetleri alanını yakından ilgilendiren bir otorite olan DSÖ, sağlık kurum/kuruluşlarında çalışanların duydukları korkunun biyolojik, kimyasal, fiziksel, ergonomik, psikolojik, yangın ve patlama ve elektrik tehlikelerine ilişkin algıdan kaynaklı olduğunu raporlamıştırn ${ }^{\mathrm{n}}$. Literatürde yer alan diğer yazılar incelendiğinde, korkuyu ele alan çalışmaların daha çok çalışanların hizmet sunumu sürecinde meslekle ilgili hastalıkların kendilerine bulaşmaları yönünde duydukları korku eksenli olarak karşımıza çıkmaktadır. $\mathrm{Bu}$ hastalıkların başında HIV, Tüberküloz ve Hepatit B gelmektedir. Güvenli olmayan uygulamalar ile sağlık çalışanları (özellikle de hekim ve hemşireler) bu hastalıkların kendilerine bulaşma riskinden dolayı sürekli olarak endişe içerisindedirler. Sağlık çalışanlarında korku söz konusu olduğunda bunu farklı kapsam ve nitelikte ele alan çalışmalar olduğu anlaşılmaktadır. Toohill, Fenwick, Sidebotham, Gamble ve Creedy, (2018), ebelerde travma ve korku hususunu ele almışlar ve özellikle korkunun doğum deneyimleri ile yakından ilişkili olduğunu saptamışlardır. Elde edilen bu sonuç oldukça önemlidir zira hastalara sunulan hizmet ve bakımın kalitesi hastanın kendisini ne düzeyde güvende hissettiği ile yakından ilişkilidir. Buna paralel olarak Dahlen ve Caplice (2014), ebelerde doğum sırasında kaygı ve korkunun bulunmasinın hastanın korkusunu artırdığını ve hastanın kalite algısına büyük ölçüde zarar verdiğini ileri sürmüşlerdir. Dolayısıyla da sağlık çalışanlarında bu tür klinik korkuların bulunması hizmet kalitesi algısının yanı sıra sağlık sonuçları üzerinde önemli etkiler oluşturmaktadır (Toohill vd., 2018). Sağlık çalışanlarının korkusu söz konusu olduğunda akla ilk gelen konulardan biri şüphesiz ki tıbbi hatalar olarak karşımıza çıkmaktadır. Ortaya çıkan tıbbi hataların raporlanıp raporlanmaması çoğunlukla çalışanların suçlanma ve cezalandırılması korkusu ile ilişkilidir. Diğer yandan, çalışanların meslektaşlarının cezalandırmaya maruz kalma ihtimali ile ilgili şüpheleri de raporlama davranışlarını etkilemektedir (Castel vd., 2015). Sağlık çalışanlarında korku duygusunu başka bir boyutta ele alan çalışmalar da bulunmaktadır. Bu çalışmalarda (Bhatnagar, 2013; Kumar, D’Souza \& Sisodia, 2013) profesyonellerde

\footnotetext{
Bu bilgi https://www.who.int/occupational_health/topics/ hcworkers/en/ adlı internet adresine 1.11.2018 tarihinde erişilerek edinilmiștir.
} 
gelişmesi muhtemel ölüm korkusunun onların duygusal iyilik hali ve ruhsal gelişimleri üzerinde olumsuz etkiler oluşturacağı değerlendirilmiştir. Deffner ve Bell (2005) hemşireler özelinde ele aldıkları çalışmalarında, hemşirelerde kaygı ve korku duygularının yaşanması sonucunda hasta ve hasta ailesi ile yapılan iletişimin zarar göreceğini raporlamıştır. Buna paralel bir çalışmada (Peck, 2009) bu tür duyguların yaşanması ile profesyonel hasta iletişiminin olumsuz etkileneceği ileri sürülmüştür. Çoğunluğu hemşirelerin oluşturduğu bir başka çalışmada (Black, 2007), çalışanlarda söz konusu duyguların yaşanması ile hastaya yüksek kalitede hizmet sunumuna olanak sağlayan profesyoneller arası işbirliği ve bilgi paylaşımının olumsuz etkileneceği vurgulanmıştır. Nia, Lehto ve Ebadi (2016), yaşanan bu tür olumsuz duyguların sağlık hizmeti sunumu boyunca profesyonel - hasta ve ailesi arasında çeşitli sürtüşmeleri de beraberinde getireceğine işaret etmiştir. En nihayetinde korku duygusunun beraberinde getirmiş olduğu hasta deneyimleri, hastanın kalite algısı üzerinde olumsuz etkiler yaratabilmektedir. Düşük tatmin düzeyi ile sağlık kurumundan ayrılan hastada kalite algısının düşüklüğünün beraberinde getirmiş olduğu kuruma yönelik olumsuz imaj algısı, hastanın gelecekte bu kurumdan hizmet alma davranışını önemli ölçüde etkilemekte ve düşük kalitenin beraberinde getirmiş olduğu maliyetler, memnuniyetsizlik ve bozulan imaj kurum açısından önemli sonuçlar oluşturabilmektedir (Boone \& Kurtz, 2016). Hangi tür korku söz konusu olursa olsun (buna sağlık çalışanının kendisinin sürekli olarak gözetlendiğine ilişkin korkusunu ifade eden panoptik korku dâhil) sağlık çalışanlarının hizmet sunumu ve hasta deneyimi ve sonuçları üzerinde önemli etkiler oluşturabilmektedir. Genel olarak değerlendirildiğinde, insan üzerinde yıkıcı etkileri bulunan korku duygusunun hayati nitelikte olan sağlık hizmetlerinin sunum sürecinde sağlık çalışanlarının davranışlarını olumsuz olarak etkilemesi ortaya çıkaracağı riskli sonuçlar nedeniyle sağlı sistemleri için son derece zararlıdır. Dolayısıyla da sağlık çalışanlarının ve en nihayetinde hastaların y1kıcı etkileri olabilen ve herhangi bir nedenden ötürü ortaya çıkma ihtimali bulunan her türlü korku duygusundan hassasiyetle korunması gerekmektedir.

Graban'ın (2011) deyimiyle, hastaneler işine bağlı çalışanlarla doludur. Bu çalışanlar işini en iyi şekilde yapmak için büyük çabalar sarf etmektedir. Herhangi bir hata ortaya çıktığında "kişi yaklaşımı" ile çalışanları suçlamak ve böylece organizasyon içerisinde bir korku iklimi yaratmak hizmet sunum sürecini olumsuz etkileyebilir. $\mathrm{Bu}$ konuyu varsayımsal bir örnekle ifade etmekte fayda bulunmaktadır. Sterilizasyon işlemi bittikten sonra malzemelerin ameliyathaneye teslim edildiği ancak ameliyat esnasında malzemenin eksik olduğunun fark edildiği, bunun üzerine ameliyathane sorumlu hemşiresinin sterilizasyon birim sorumlusunu aradığı, eksik malzemenin olduğunu ve konteynırın içerisinde set formunun olmadığını bildirdiği varsayılsın. Birimin yeni sorumlu hemşiresinin, herkesin içerisinde sert bir tavırla hemşirelere bağırdığı ve küçük düşürücü şekilde "kim yaptı bunu, yapan kişi bir daha yapmayacak" şeklinde söylemlerle birimde çalışanların iş motivasyonunu düşürdüğü ve sorunun nedenine inmeden, sadece kişiye yönelik saldırgan bir davranışla hemşirelere karşı psikolojik bir baskı uygulaması sonucunda birimde çalışanlarda korku, endişe ve hata yapma korkusunun meydana geldiği düşünülsün. İlerleyen süreçte ise birim sorumlusunun yapılan her hatada çalışanlara bağırması, hemşireler ve diğer personeller arasında gruplaşmaya, iş motivasyonunun düşmesine, iş verimliliğinde azalmaya, hemşirelerde başka birimlere gitme arzusunun oluşmasına, hemşirelerin sorunlarını birim sorumlusuna değil de idari birimlere doğrudan iletmesine ve birim içerisinde çatışmalara yol açabilir. Sorumlu hemşirenin sorunu sistemik yaklaşımla ele almaktan ziyade çalışanlara yönelik suçlama ve sözlü biçimde sert davranışlar sergileme yöntemini seçmesi çalışanların kronik bir korku duygusu yaşamasına neden olabilir.

Yukarıda ele alınan olayda sorumlu tarafından benimsenen yaklaşım yerine, "sistem yaklaşımı" ile özellikle de sistem ve süreçlerin iyileştirilmeye çalışılması daha isabetli bir yaklaşımdır. Bu anlayış, çalışanlar üzerinde oluşturduğu etkiler kadar hastalar üzerinde de önemli etkiler oluşturabilmektedir. $\mathrm{Bu}$ görüşe paralel bir çalışmada (Beyatlı, 2017), hastane - misafirinin hasta olduğu bir otel - içerisinde bir emniyet havası ve samimiyet hususunun hastalar üzerinde olumlu etkiler oluşturacağına dikkat çekilmiştir. Bu hedef(ler)in en önemli öncüllerinden biri kuşkusuz liderlik desteğidir. Kanımızca yalın yönetim felsefesinin benimsenmesiyle bu tür kronik yönetsel problemlerin üstesinden gelinebilir zira söz konusu felsefede liderler aktiftir ve organizasyon içerisinde sistem ve süreçlerde değer akışını ele alıp müşteri için değer yaratmayan tüm prosedürleri elimine etmeye çalışırlar. Herhangi bir hata ortaya çıktığında ise "kim" yerine "neden" sorusunu sorarak problemin kök nedenlerini ortaya çıkarmayı hedefler. Bu hususa varsayımsal bir örnek olarak bir hastane ziyaretini ele almak çalışma açısından önem arz etmektedir. Üst düzey yöneticiler ve hastane yönetiminin denetimi esnasında yöneticilerin, yeni doğan servisinde çalışan hemşireye iki bebeğin cinsiyeti ile ilgili bir soru sorduğu, hemşirenin verdiği cevapların yanlış olması üzerine sorumlu hemşirenin duruma müdahale ettiği, bunun üzerine yöneticilerin hemşireye niçin yanlış söylediğini 
sorduğunda ise hemşirenin nöbet saatinin uzun olduğundan ve dikkatsizliğinin bu sebepten kaynaklı olduğunu ifade ettiği varsayılsın. Bunun üzerine ertesi gün ilgili kurumun yöneticilerinin, çalışanların nöbet saatlerinin düşürülmesi için çeşitli girişimlerde bulunması ve problemlerin böylesine bir anlayışla ele alınıp çözüm geliştirilmesi sağlık çalışanlarının kendilerini güvende hissetmelerine katkı sağlayabilecektir. $\mathrm{Bu}$ durumu sosyolojik açıdan düşünmekte fayda bulunmaktadır. Sosyal bir birim olarak hastanelerde çalışanların kendi aralarında ve hastalar ile etkileşimde bu bilim dalının bize önemli şeyler söyleyeceği kanaatindeyiz. Bauman'ın (2018a) bu konu ile ilgili ileri sürmüş olduğu sözler dikkate değer olup aşağıda sunulmuştur.

"Sosyolojinin insan hayatına ve insanların bir arada yaşamalarına vermek için çok hazır olduğu büyük hizmet, paylaşılmaz özgürlüğün vazgeçilmez bir koşulu olarak karşılıklı anlayış ve hoşgörüyü yükseltmektedir. Sosyolojik düşünmek hoşgörüyü besleyen anlayışı ve anlayışı mümkün kılan hoşgörüyü artırmaktan başka bir şey değildir."

Sosyoloji perspektifinden durum değerlendirildiğinde, insanların (çalışmamızın konusu sağlık çalışanları) bir arada özgürce var olabilmelerinin anlayış ve hoşgörü gibi sosyal düzenin inşası ve sürdürülebilir kılınmasında etkili olan bu iki araca sahip olmaları gerektiği ifade edilebilir. Sağlık hizmetlerinin sunumunda çok sayıda disiplinin bir arada ahenkle çalışması gerekliliği, bu hizmetlerin sunumunda çalışanlararası anlayış ve hoşgörü gerektirmektedir. Çalışanlar-arası anlayış ve hoşgörünün temin edilmediği bir ortamda Bauman'1n (2018a, 2018b) deyimiyle, "biz" ve "onlar" olmak üzere iki farklı kutup oluşmaya başlar. Kutuplar arasında mesafenin artışı ile birlikte yalnızlaşan, yabancılaşan çalışanlar ortaya çıkmaktadır. Söz konusu çalışanlar "biz" grubunda yer almayan kişilere karşı düşmanca duygular besleme eğilimi göstermeye başlayabilmektedir. Netice itibariyle, iş yerinde barış ortamı büyük ölçüde zarar görmekle birlikte çalışanlar arasında sürtüşme ve çatışmalar baş gösterir, akut olarak gelişen olaylar belli bir süre sonra kronik bir hal almaya başlar.

Modern dönemle birlikte ortaya çıkan modern korkunun sağlık hizmetleri alanında önemli yer edindiği ifade edilebilir. Sağlık çalışanları büyük ölçüde yüksek düzeyde eğitimli ve uzmanlık gücü bulunan kişilerden oluşmaktadır ve Mintzberg (2014), uzmanlık örgütleri olarak adlandırılan hastanelerde profesyonel bürokrasinin hâkim olduğu demokratik bir rejimin varlığından söz etmektedir. $\mathrm{Bu}$ yönüyle sağlık çalışanlarının, özellikle de hekimlerin, sistem içerisinde bir otonomileri bulunmaktadır. $\mathrm{Bu}$ nedenle, sağlık çalışanlarının sistem içerisinde sürekli olarak gözetlenmesi kanımızca bu çalışanlarda tedirginlik ve rahatsızlık oluşturabilir. Panoptik gözetim olarak ifade edilen bu durum sağlık hizmetleri alanında da karşılık bulmaktadır. Dolayısıyla panoptik gözetime maruz kalan sağlık çalışanlarında kanımızca panoptik korku ve buna yönelik olarak davranış geliştirme riski söz konusu olabilmektedir.

Sağlık hizmetleri alanında çeşitli uygulamalar yolu ile sağlık çalışanlarını gözetleme ve denetleme faaliyetleri özellikle son yıllarda artış göstermiştir. $\mathrm{Bu}$ akımın içerisinde kalite felsefesi ve toplam kalite yönetimi uygulamaları ilk sırada gelmektedir. Hizmette standardizasyon sağlama ve hizmet sunucusunun davranışlarından kaynaklı varyasyonları minimize etmek amacıyla hayata geçirilen uygulama ve ölçümler kanımızca sağlık çalışanlarını gözetleyen ve denetleyen bir işlev de görmektedir. Geliştirilen tedavi protokolleri, ameliyathane işleyiş prosedürleri ve buna benzer uygulamalar çalışanların davranışlarını sıkı bir şekilde kontrol altına almaktadır. Kalite yönetiminden sorumlu kişiler tarafından, aylık düzenli kontrollerle birimlerin denetlenmesi yoluyla belirli standartlara uyulup uyulmadığı kontrol edilmektedir. Buna bağlı olarak birimlerde puanlama sistemi uygulanarak hastanenin performans puanı ortaya konmakta ve hastane çalışanlarının ek ücret ödemelerinin belirlenmesinde ise bu performans puanları etkili olmaktadır. Performans puanının düşük olduğu birimlerdeki sorumlular, yönetim tarafından tekrar değerlendirilmekte, aksaklıkların iyileştirilmesi için faaliyetler düzenlenmekte, ayrıca çalışanların iş verimliliğini arttırmak ve gerekiyorsa disiplinin sağlanması için personel değişikliği ve rotasyonlar yapılmaktadır. Birimde çalışanların yerine getirmedikleri görev ve uygulamalar için davranış değişikliğinin geliştirilmesini sağlamak amacıyla hizmet içi eğitimler, seminerler düzenlenmekte, hatta bu eğitimler zorunlu tutulmaktadır. Bu eğitimlere katılmayanlar için yönetim tarafında yazılı ve/veya sözlü uyarı yapılmaktadır. Böylece bireylerin normlara yönelik tutumu, davranışlarının geliştirilmesi ve kurallara bağlı kalması sağlanmaktadır. Ayrıca çalışanların görev, yetki ve sorumlulukları her birimde görülebilecek panolara asılmakta, bunları yerine getirmeyenler için idari işlem uygulanmaktadır. Buna ek olarak, dünya genelinde yaygın olarak benimsenen ve sağlık hizmetleri alanında hayata geçirilen performansa dayalı ödeme sistemi bir gözetim ve kontrol arac1 olarak kabul edilebilir. Ulutaş'ın (2002) ifade ettiği gibi, performansa dayalı ödeme sisteminde çalışanların emeği ile ücreti arasında bir ilişki kurulmaktadır. Dolayısıyla da ücret baskısı emek sürecinin her anında profesyoneller tarafindan 
hissedilmektedir. Kanımızca bu durum, tıpk1 Bentham/Foucault'un panoptikonunda olduğu gibi sağlık çalışanlarının farklı davranışlar sergilemesine yol açabilmektedir. Bir hastanenin sterilizasyon birimi ile ilgili varsayımsal olay bu duruma önemli ölçüde açıklık getirmektedir. Ameliyathaneden kirli gönderilen malzemelerin sterilizasyonda karşılanması, sayımı ve kayıt işleminin sadece bazı personele bırakıldığ sorumlu hemşire tarafindan düzenli olarak kontrol edilmemesi nedeniyle gelen malzemeleri kontrol etmemesi ve malzeme teslim formu evraklarını kayıt altına almaması, birimde malzemelerin eksik çıkmasına ya da hassas malzemelerin kırılması sonucu malzeme kaybı yaşanmasına neden olduğu varsayılsın. Sayımın iyi yapılmaması sonucunda ise eksik malzeme olup olmadığının bilinmemesi, malzemenin ya ameliyathanede çöpe atılması ya da hastane içinde kalabileceği sonucunu doğurabildiği söylenebilir. Sonuç olarak, hasta için kullanılacak malzemenin yokluğu iş verimliliğ ve ameliyat performansının olumsuz etkilenmesi gibi sonuçları beraberinde getirebilir. Ameliyathane yönetiminin sterilizasyon birimi hakkında sözlü uyarı ve yazılı tutanak ile yaptırım uygulaması, bu yaptırımın çalışanlarda disiplini sağlamasına ve iş verimliliğinin artmasına katkıda bulunduğu düşünülebilir. Aynı zamanda birimde, gözetim ve kontrol mekanizmasının işlerliğini sağladığı, malzeme ve mali kayıpların önüne geçildiği de olası sonuçlardan biridir. Kontrol mekanizmasının işlerliğinin sağlanması, işlerin daha düzenli ve disiplin içerisinde yapılmasına olanak sağlarken çalışanlarda korku ve sorumluluk duygusunun artmasına neden olabilir. Öyle ki, bu durumun çalışanlarda davranış değişikliğine yol açabileceği, birbirleri üzerinde de denetim mekanizması kurmalarına neden olabileceği ifade edilebilir. Emek sürecinin her aşamasında ücret baskısının hissedilmesi durumuna benzer şekilde bu durumda da emek sürecinin her aşamasında çalışanın kendisinin sürekli olarak gözetim altında olduğunu hissetmesine, bu nedenle de çalışan(lar) tarafindan doğal olmayan davranışlar sergilenmesine yol açabilir.

Türkiye'de hayata geçirilen ve hizmet sunumunu finanse etmenin temel yöntemlerinden biri olan "global bütçe" uygulamasının sağlık hizmet sunumunu önemli ölçüde etkileyeceği yönündeki görüşler kuvvetlenmektedir. Sağlık sisteminde hayata geçirilen bu uygulama ile sağlık sistemlerinin harcamalarını kısıtlamak ve böylece bütçe üzerindeki mali yükü azaltmak temel hedeftir. Harcamaların kısıtlanması, operasyonel veya işletimsel düzeyde sağlık çalışanlarının davranışlarını arzulanan yönde değiştirmek anlamına gelmektedir. Yönetimce verilen talimatlar ve sağlık profesyonelleri üzerindeki baskı geleneksel hizmet sunum davranışını değiştirme potansiyeline sahiptir. Bunun da ötesinde profesyonelleri - özellikle de hekimleri - yakından ilgilendiren mevzuat, çalışanların yakın bir gözetim altında tutulduğunu kolaylıkla gözler önüne sermektedir. Maliye Bakanlığı'nın "Bütçe Uygulama Talimatı", Sosyal Güvenlik Kurumu'nun MEDULA sistemi, "Sağlık Uygulama Tebliğii" ve "Fatura İnceleme Usul ve Esasları" vb. uygulamalar ile hekim sürekli olarak gözetlenmektedir. Hekim, hastasının tedavisine yönelik vereceği kararda tüm bunları göz önünde bulundurmak durumundadır. Sağlık kurum/kuruluşlarında kartlı geçiş sistemleri, kameralar ve hastane otomasyon sistemleri çalışanları izlemenin temel aracı olarak değerlendirilmektedir. Buradaki temel amaç, özdisiplin ve öz-denetim erozyonu pahasına da olsa denetimin içselleştirilmesi olarak ileri sürülmüştür (Ulutaş, 2002). Kanımızca çeşitli otoriteler tarafından hekimin sürekli olarak izleniyor olması hekimde bir tedirginlik ve korku halinin ortaya çıkmasına neden olabilir. En nihayetinde bu durum hekimlerin psikolojik yönden sağlıksız olmalarına ve hizmet kalitesinin ve sağlık sonuçlarının olumsuz etkilenmesine yol açabilir.

Böyle bir durumun ortaya çıkmasını önlemek için hastane yöneticileri kurmak istedikleri gözetimkontrol ile sağlık çalışanlarının işlerini daha rahat yapabilmeleri arasında hassas bir denge kurmak durumundadır. Sağlık çalışanlarına gözetim altında olmaksızın hizmeti doğru ve etkili üretme hazzı ve iklimi daha etkili yollarla sağlanmalıdır. Başka bir anlatımla, öz denetimle sağlık çalışanlarının dişarıdan gözetilip gözetilmediklerini önemsemeksizin işlerini yapabilmelerine ilişkin yeni bir durum geliştirilmelidir.

Sağlık sistemi içerisinde panoptik gözetimde öne çıkan en temel aktörlerden biri şüphesiz ki hastalardır. Hasta haklarının gelişimi, sağlık hizmetlerinin hasta merkezli olma yönünde geçirdiği evrim, bu konuda hayata geçirilen kanun ve yönetmelikler panoptik gözetimde hastaların önemli olduğunu göstermektedir. $\mathrm{Bu}$ durumu hastane içerisinde birkaç somut örnekle açıklamakta yarar bulunmaktadır. Örnek olarak, dâhiliye servisinde yatan hastaların çoğunluğu kronik rahatsızlığı olan ve tedavisi yıllarca devam edebilen hastalardir. $\mathrm{Bu}$ hastalar, kendilerine uygulanan ilaçların isimlerini ve ilaçlarının verilme zamanını çok iyi bilmektedirler. Özellikle diyabet ve hipertansiyon hastaları bunun en iyi örneklerini oluşturmaktadır. $\mathrm{Bu}$ hastalar, kendi hastalıkları konusunda internet ya da çeşitli programlardan bilgiler edinmekte, deneyimlemiș oldukları hastalıklarına bağlı komplikasyonlar (diyabet hastalarında hipoglisemi ya da ketoasidoz vb.) hakkında da genel bilgiye sahip olmaktadırlar. Kendilerinde meydana gelen en küçük değişikliği, aynı zamanda hemşirenin uyguladığı tedaviyi veya 
zamanında uygulanmayan ilaç ve girişimleri anında doktora iletebilmektedirler. Hemşire bu süreçte hastanın durumunu sürekli olarak gözlemlemekte, tedaviyi zamanında uygulamaya çalışmakta, eksik ya da yanlış tedavi uygulamamak için son derece korku ve kaygı yaşamakta, iş stresini ise daha fazla hissedebilmektedir.

Sağlık alanının her biriminde hasta tarafindan yapılan gözetimin varlığından söz edilebilir. Özellikle pediatri servislerinin bu konuda daha hassas olduğu söylenebilir. Pediatri servislerinde çocukların ebeveynler eşliğinde serviste yatışının olması, çocuğa girişimsel işlem sırasında özellikle annelerin duygusal tepkisinin fazla olması ile birlikte tedaviyi uygulayan hemşireye karşı sergilenen tavirlar bazı zamanlar sert olabilmektedir. $\mathrm{Bu}$ durum sağlık çalışanının işini rahatlıkla yapmasına engel teşkil ederken, annenin sergilediği tavır karşısında hemşirenin yaklaşımı son derece önem kazanmaktadır. Sağlık çalışanının iletişiminin sağlıklı olması, anne ve çocuğun daha rahat hizmet almasını sağlarken, sağlık çalışanı üzerinde gözetimin yarattığı stresi de azaltmaktadır. Ayrıca hemşirenin çocuğa yaptığı her bir uygulamayı hemşire gözlem kâğıdına yazması gerekmektedir. Çünkü hekim, çocuğun vital bulgularının takibini, uygulayacağı tedavi dozunu, çocuğun muayene bulguları ile birlikte ek bir tedavi uygulama kararını, tahlil ve tetkikler 1şığında hemşire gözlemini esas alarak tedaviyi sonlandirabilmekte ya da tedaviye devam etme kararını alabilmektedir. Hemşireler, hasta ve yakınları tarafından sürekli olarak gözetlendiğinden tedaviyi yanlış veya eksik uygulama korkusunu, yaptığı girişimden uyarı alma endişesini yaşayabilmekte, ayrıca hastanın durumunun kötüleşmesi ile yaşanabilecek hukuki süreç karşısında kaygı ve tedirginlik gibi çok sayıda olumsuz duygu yaşayabilmektedir.

Genel olarak değerlendirildiğinde, sağlık hizmeti sunum sürecinde sağlık profesyonel(ler)inin davranışlarını etkileyecek çok sayıda faktörden söz edilebilir. Kanımızca sağlık çalışanlarında istenen yönde davranış geliştirmede ve bu davranışları biçimlendirmede Mintzberg'in (2014) ileri sürdüğü eğitim ve doktrinlemeden faydalanmak oldukça önemlidir. Eğitim, "işle ilgili becerilerin ve bilginin öğretildiği süreç" iken doktrinleme, “örgütsel normların edinildiğì" süreç olarak ifade edilmiştir. Sağlık profesyonellerinin eğitim aldıkları süreçte standart bilgi ve becerilerin kazandırılmasına ek olarak örgütte çalışmaya başladığında doktrinleme yolu ile çeşitli normların benimsetilmesi profesyonelin aktif katılımını gerektirdiği için daha sürdürülebilir bir gözetim ve denetim anlayışı sağlayabilir. Profesyoneller bu uygulamaların doğru olduğuna inanırlarsa, davranışlarıyla da bunları - her ne kadar Bauman (2017b), bu durumun hiç de kolay olmadığını, genellikle şiddetli ve başlangıçta acı ve rahatsızlık veren, düşünce değişikliğinden fazlasını gerektirdiğini belirtse de - doğru kılmak için çaba sarf eder. Profesyonelleri sistem içerisinde yalnızlaştırmadan ve sisteme yabancılaştırmadan ideal düzeyde sağlık hizmeti sunmalarında bu hususlar önemsenmelidir. Bu görüşe paralel olarak Akerlof ve Kranton (2016), iyi bir yönetimin çalışanlarını yabancılaştırıp dışarıdakiler grubuna değil, motive ederek içeridekiler grubuna dâhil etmesi gerektiğini ileri sürmüşlerdir.

\section{TARTIŞMA VE SONUÇ}

Bu çalışmada, sağlık hizmetleri alanında çalışanlar üzerinde panoptik gözetimin yaratabileceği korku ve buna yönelik olarak geliştirilebilecek davranışlar Bentham ve Foucault'un yaklaşımları benimsenerek ilgili literatür 1şığında değerlendirilmiştir. Panoptikon, günümüz modern gözetimi için çok farklı anlayışlar sağlamıştır ve teknolojinin hızlı gelişimi ile her alanda kendisine yer edinmiştir. Panoptik gözetim sadece belli organizasyonlar içerisinde değil hayatın her alanında yarattığ sonuçlar itibariyle insanlar tarafindan dikkat edilen bir husus haline gelmiştir.

İnsan yaşamı ile ilgili olarak ortaya atılan ve belli bir bütünlük ihtiva eden görüş(ler), ilgilenilen olgu ile ilgili gelinen son noktayı ve evrensel olduğunu ileri sürmekten uzaktır. $\mathrm{Bu}$ durum şüphesiz ki panoptikon ile ilgili olarak ileri sürülen görüşlerde de geçerlidir. Literatürde panoptikonun ağır, hantal, maliyet-etkili olmadığı ve geçerliğini kaybettiği yönündeki görüşler (Bauman \& Lyon, 2018; Mathiesen, 1997) kanımızca isabetli değildir zira günümüzde modern yapıların inşasında - şehir hastaneleri buna örnek verilebilir- çok büyük paralar harcanmaktadır. Böylesine büyük ve yüksek maliyetli yapılar içerisinde panoptik eğilim geçtiğimiz yüzyıllara göre çok daha arzulanır hale gelmiştir. Hangi terimleri kullanırsak kullanalım, hayatın her alanında - buna sağlık hizmetleri de dâhil - gözetim ile ilgili devrim niteliğinde gelişmelerin olduğu açıkça ortadadır. Sadece yeni gözetim biçimlerinin değil, toplumu ayakta tutacak yeni ilkelerin oluşmaya başladığına şahitlik etmekteyiz.

Yönetim alanında önemli düşünürlerden Mintzberg'in (2014) hastanelerin demokratik profesyonel bürokrasinin hâkim olduğu uzman örgütler olduğu görüşü, günümüzde revize edilmesi gereken paradoks niteliğinde bir görüş olarak değerlendirilebilir zira bu görüşe göre, profesyonel bürokraside profesyonellerin otonomisi hâkim olup yönetsel kararlar aşağıdan yukarıya doğru akmaktadır. Günümüze bakıldığında, sağlık 
hizmetleri alanında profesyonel bürokrasiden makine bürokrasisine doğru bir evrim yaşandığ 1 ileri sürülebilir. Hizmet sunum süreçleri kalite felsefesi adı altında standardize edilmiş olup profesyoneller Bütçe Uygulama Talimatı, Sağlık Uygulama Tebliği ve Fatura İnceleme Usul ve Esasları gibi yasal metinlerce kuşatılmıştır. Böyle bir durum ile karşı karşıya iken hastanelerde profesyonel bürokrasinin demokratikliğinden ziyade, demokratiksizleştirilmesi yönünde iradeler ortaya konduğu ileri sürülebilir. Panoptik gözetim ile ilişkilendirilebilecek bu uygulamalar ile sağlık profesyonellerinin yakından gözetlendikleri, bu nedenle de profesyonellerin hastanın sağlık durumu ile ilgili verecekleri kararlarda ayrica otoritenin beklentisini de göz önünde bulundurduğu stres ve korku yaratma ihtimali oldukça yüksek bir durumun varlığından söz edilebilir.

Bentham'ın panoptikon modeli ile hayal ettiği faydacı toplum ideali, günümüzde de kolaylıkla anlaşılabilecek bir hedef olarak değerlendirilebilir. Sağlık hizmetleri, hastaya sunulan yaşam hizmetleri niteliğindedir ve profesyoneller tarafindan bu hizmetlerin faydasının en çoklanması yönünde davranışlar sergilenmesi gerekmektedir. Sağlık kurum ve kuruluşları içerisinde sağlık profesyonellerinin gözetlenmesi ile otoritenin yanı sıra, hastanın beklentilerine uygun davranışların teşvik edilmesi faydalı sağlık hizmetlerinin sunumu için temel bir gerekliliktir. Dolayısıyla Bentham'ın faydacı görüşü sağlık hizmetleri alanına oldukça uygun bir yapı göstermektedir. Bentham'ın ileri sürdüğü "en çok sayıda kişiye en yüksek düzeyde mutluluk" hedefini temin etmenin bir yolu da insanlara ihtiyaç duyduklarında sağlık hizmetlerini en etkili şekilde sunmaktan geçmektedir. Bu yönüyle sağlık hizmetleri alanı fayda kavramının son derece kritik olduğu önemli alanların başında gelmektedir. Ancak burada unutulmaması gerekli bir husus, profesyonellerin ne ölçüde gözetim altında tutulması gerektiğidir. Herkesin faydasını temin etmek adına sınırsız bir şekilde gözetim mekanizmasına başvurmanın ve profesyonellerin mahremiyet sınırlarını aşındırmanın olumlanabilir bir yanının olmadığı düşünülmektedir. Profesyonellerde yönetim tarafından yapılan aşırı gözetime bağlı olarak rahatsızlık ve tedirginlik şeklinde ortaya çıkabilecek korkunun göz önünde bulundurulması gerekmektedir.

Bentham'ın kişilerin tanınabilirliği ve gözetimin toplumun geneline yayılması gerektiği yönündeki görüşleri günümüzde büyük ölçüde karşılık bulmaktadır. Hayatın her alanı çeşitli otoriteler tarafından kameralar ile gözetlenmekte olup aykırı durumlar anında saptanabilmektedir. Sağlık alanında duruma bakıldığında, sağlık kurumlarında her alan kameralar tarafindan izlenmektedir ve ortaya çıkan problemlerde sorumlular anında tespit edilebilmektedir. Sağlık alanında şiddetin çarpıcı şekilde artış gösterdiği son yıllarda sağlık kurumlarında gözetim faaliyetlerinin artırılması sağlık çalışanlarının kendilerini güvende hissetmelerine katkı sağlayabilecektir. Bunun yanı sıra, sağlık sistemlerinde artık herkesin kimlik bilgilerini içeren parmak izleri bulunmaktadır ve hastalar bu sistemi kullanarak sağlık hizmetine erişim sağlamaktadır. Dolayısıyla sağlık alanı özelinde Bentham'ın hayalinin gerçekleştirilmesi yönünde önemli adımlar atıldığı söylenebilir. Buna ek olarak, hasta ve çalışan sağlığı ve hukukunun korunması için en yeni teknolojilerden yararlanmak önemli ve gereklidir. Buna karşın, çalışanların gözetiminde ölçü hususuna dikkat etmekte fayda olduğu değerlendirilmektedir. Gözetimde uzlaşılan ölçünün ilgili paydaşlar üzerinde oluşturabileceği etki ve bu etkinin sonuçları hassasiyetle değerlendirilmelidir.

Foucault'un modern gözetimi ifade etmek üzere kullandığı panoptikon metaforu, sağlık profesyonellerinin öz-disiplin ve kendine hâkim olma yönünde onlara yetenek kazandırabilir. Özyönetim kabiliyeti gelişen profesyoneller normalize edilmiş davranışları sergileme yönünde irade gösterebilirler. Foucault'un insanlar üzerinde bask1 ve güç uygulamanın yerine onları gözetlemenin beklenen davranışları yerine getireceği yönündeki görüşü sağlık hizmetleri alanında kolaylıkla anlaşılabilir. Sağlık profesyonelleri iş yaşamı içerisinde büyük ölçüde ellerinde bulundurdukları uzmanlık gücünü kullanmak istemektedir ve bu gücün sarsılması onları tedirgin edebilir. Çalışmanın başında geçen olay bu durumu daha iyi açıklamak için etkili bir örnektir. Sağlık kurumunun norm ve beklentilerine uygun davranışlar sergilemesi için profesyonele yapılan yazılı veya sözlü uyarılar profesyonellerde bir itibarsızlık veya çalışanlar arasında deşifre olma gibi bazı rahatsızlıklar yaratabilir. Bunu engellemek üzere profesyonellerin kendilerinden norm ve beklentilere uygun davranış göstereceği oldukça kabul edilebilirdir. Bu durum elbette ki sınırsız ölçüde gözetimi olumlar nitelikte olarak değerlendirilmemelidir. Çalışanların gözetim mekanizması kullanılarak yönetilmeye çalışılması ve buna ilişkin uygulamalar, sağlık sisteminin performansının iyileştirilmesi ve geliştirilmesinde önemli bir engel olarak görülen çalışan davranışlarının daha etkin yönetilebilmesi için potansiyel araçlar olarak düşünülebilir. Önemli ölçüde varyasyon gösteren ve sağlık sistemi ve hasta sonuçları üzerine olumsuz etkileri olabilen profesyonel davranışlarının normalize edilmesi elbette ki oldukça önemlidir. 
Bauman ile yapılan bir röportajda, Bauman'ın modern dönemle birlikte insanların artık özgürlük ve güvenlik arasında bir seçim yapmaları gerektiği yönündeki görüşü sağllk sistemi içerisinde benzer şekilde karşılık bulmaktadır. Sağlık profesyonelleri geleceklerini ve yaşadıkları süre boyunca refahlarını garanti altına almak için kendilerini sosyal güvenlik şemsiyesinin altına alarak gelecekte muhtemel daha düşük standartlarda yaşama kaygısından kendilerini kurtarmaktadırlar. Böylece sağlık çalışanlarının bir açıdan güvenlik kaygısından kurtulduğu söylenebilir. $\mathrm{Bu}$ güvenlik fonksiyonuna karşı çalışanlar birtakım özgürlüklerinden vazgeçmekte ve emeklerini otoritenin beklentileri yönünde harekete geçirmeleri gerekmektedir. Emeklerini harekete geçirirken de otorite tarafindan ne tür davranışlar sergilediklerini kontrol etmek üzere yakından gözetim altında tutulmaktadırlar. Dolayısıyla da modern çağda sağlık çalışanları kendi güvenliklerini temin etmek üzere birtakım özgürlüklerinden vazgeçtikleri ve ileriki hayatlarında belirsizliğin üzerlerinde oluşturduğu baskıyı özgürlüklerini feda etme pahasına kabul ettikleri söylenebilir. Ortaya çıkan bu durum, kişilerin değil, kişilerin davranışlarının gözetim altında tutulduğu bir durum olarak değerlendirilmelidir. Güvenliklerini temin eden çalışanların özgürlüklerini sınırsız olarak feda ettikleri bir durum söz konusu değildir. Sağlık sistemi içerisinde çalışan hakları ve mahremiyeti oldukça önemsenmelidir ve çalışan davranışlarının kontrol edilmesinde belki de en önemli husus, hasta güvenliği ve sağlığının korunması ve geliştirilmesi olarak değerlendirilmelidir.

Yöneticiler için norm ve beklentilere uygun davranışlar sergileyen çalışanlar oldukça değerlidir. Manokha'nın (2018) panoptikonun 21. yüzyılda yönetim için ayrıcalıklı önem arz ettiği yönündeki görüşü kanımızca isabetli bir yaklaşım olup sağlık sistemi içerisinde binlerce çalışanın kontrol edilmesi ve aykırı davranışların saptanıp çözüm geliştirilmesi için son derece önemlidir. Sağlık sistemi içerisinde çalışanların davranışları kontrol edilmeden ve hizmet kalitesini olumsuz etkileme potansiyeli bulunan varyasyonlar giderilip standardize edilmeden sistemin kendisinden beklenen sonuçları üretmesi mümkün değildir. $\mathrm{Bu}$ amaçla sağlık sisteminde son yıllarda hayata geçirilen uygulamalar, sağlık çalışanlarının davranışlarını kontrol ve standardize etme amacı gütmektedir. Toplam kalite yönetimi ve yalın yönetim uygulamaları, performansa dayalı ödeme ve global bütçe uygulamaları vb. uygulamalar hizmet sunucularının özellikle de hekimlerin kaynak kullanım davranışlarını gözetleme ve kontrol amaçlı hayata geçirilen panoptikonik uygulamalar olarak değerlendirilebilir. Bentham ve Foucault 'un gözetim mekanizmasına ilişkin saptamaları göz önüne alındığında, günümüzde sağlık alanında çalışan davranışlarının gözetilmesinde ortaya çıkan ve kullanılan teknolojilerin kendisinden beklenen rolü yerine getirdiği söylenebilir. Bu durumda belki de dikkat edilmesi gerekli olan husus, çalışanların mahremiyet alanına saygı duyularak ortaya çıkabilecek herhangi bir mahremiyet aşınmasının önüne geçilmesi, hasta sağlığının korunması ve geliştirilmesi için çalışanların davranışlarının gözetim mekanizması marifetiyle arzulanan sonuçlar yönünde iyileştirilip geliştirilmeye çalışılmasıdır.

Panoptikon modelinin sağlik hizmetleri için sağlayabileceği faydalar bulunmasının yanı sıra, söz konusu faaliyetlerin profesyoneller üzerinde psikolojik hasarlar yaratabileceği ihtimali sürekli olarak göz önünde bulundurulmalıdır. Profesyonellerin sürekli olarak gözetlenmesi onları huzursuz edebilir, onlarda tedirginlik ve kayg1 uyandirabilir. Yaşamsal hizmetler sunan profesyonellerin motivasyon ve performans düzeylerinin ortaya çıkacak bu olumsuz durumlardan kolaylıkla etkilenebileceği dikkate alınmalıdır. Hizmet sunum süreci boyunca sürekli olarak gözetim altında olduğunu hisseden ve düşünen ister bir hekim isterse de bir hemşire olsun, bu kişilerde hastanın hizmet kalitesi algısı üzerinde olumsuz etki uyandırabilecek anormal davranışların ortaya çıkması büyük bir olasılıktır. Hastanın hizmet sunucuları ile deneyimlediği ilişkilerin kalitesi planlanan sonuçlar üzerinde etkili olduğu için bu durum önemsenmelidir. Bu nedenle, sağlık çalışanlarını gözetim altında tutmak amaçlı geliştirilen her yöntemde çalışanlar üzerinde bir korku duygusu oluşturulmadan, yapılan faaliyetlerde büyük bir özen gösterilmesi gerekmektedir. Sistem içerisinde sağlık profesyonellerini itibarsızlaştıran ve çalışanlar arasında belli bir kusur ile deşifre etme anlayışlarının yerine çalışanlar arasında saygı ve barış ikliminin teşvik edildiği bir ortam oluşturulmalıdır. $\mathrm{Bu}$ tür bir ortamın oluşturulmasında sağlık yöneticilerine büyük iş düşmektedir. Sağlık yöneticisi perspektifi ile olay değerlendirildiğinde, sağlık çalışanlarında sürekli gözetim yoluyla panoptik korku oluşturulmaması gerektiği unutulmamalıdır. Yoğun iş yükü ve stres altında çalışan sağlık çalışanlarının motivasyonu önemsenmelidir. Dolayısıyla sağlık sistemi içerisinde hayati rolleri bulunan çalışanların motivasyonlarına zarar verme potansiyeli bulunan her türlü girişimde büyük bir hassasiyet ile davranılması gerektiği önerilebilir.

$\mathrm{Bu}$ çalışmada yapılan tartışmalardan görülebileceği üzere, sağlık hizmetleri alanının sosyologlardan öğrenebileceği pek çok şey bulunmaktadır. 
Bentham'dan Foucault'a, ondan Bauman'a kadar uzanan panoptikonun tarihsel yolculuğunda pek çok gelişmeler yaşanmıştır. Yaşanan tüm bu gelişmeler şüphesiz sosyal yaşam üzerinde değiştirici ve dönüştürücü nitelikte etkiler yaratmaktadır. Sosyologlar tam da bu noktada çok değerli bir misyon ile karşımıza çıkmaktadırlar. Sosyologlar, sosyal yaşamı etkileyen tüm gelişmeleri çok yakından izlemekte ve sosyal düzenin inşasında önemli teoriler geliştirmektedirler. Sağlık hizmetleri alanı da sosyoloji bilimi ile yakın etkileşim içerisindedir. Bentham'dan günümüze kadar yaşanan tüm gelișmelerden sağlık hizmetleri alanı da payını almıştır. Bentham, Foucault ve Bauman'ın ileri sürmüş olduğu görüşler yakından değerlendirildiğinde, günümüzde ve gelecekte sağlık hizmetlerinde düzen inşa etmede sosyologların fazlasıyla söz sahibi oldukları yönündeki tarihi gerçeklerin gözler önüne serildiğine kolaylıkla şahit olunmaktadır. Sosyal ilişki ve etkileşimlerin önemli ölçüde yüksek olduğu hastanelerde sağlık profesyonellerinin hizmet sunum davranışlarını etkileyebilecek çeşitli müdahaleler söz konusu olduğunda, sosyolojinin ve sosyologların fikirlerine başvurmak etkili bir yaklaşım olacaktır. Akışkan örgütler olarak değerlendirilebilen hastanelerde alt kademelerden başlamak üzere yenilikler teşvik edilebilir ve hızlı toplumsal ve teknolojik değişimlere daha kolay uyum sağlama yeteneği geliştirilebilir. Söz konusu yeteneğin kazanılmasında toplumsal yaşamı etkileyen gelişmeleri yakından takip eden bilim insanlarının görüşlerine başvurmak oldukça önemlidir. İnsan faktörü göz önünde bulundurulmadan, mekanik yaklaşımlar ile geliştirilecek sağlık hizmeti sunum süreçleri profesyonelleri sağlık sistemine küstürebilir ve yabancılaştırabilir.

Genel olarak değerlendirildiğinde, sağlık hizmetleri alanı, informal ilişki anlayışından formal ilişkiler anlayışına doğru evrim geçirmektedir. Hizmet kalitesini temin etme, harcamaları kısitlama vb. amaç ve hedeflerle çıkılan yolda sağlık hizmeti sunumuna ilișkin tüm süreçler formal zeminde standardize edilmekte olup profesyonel davranışları gittikçe daha fazla biçimlenmektedir. Şüphesiz ki bu tür adımların hizmet sunum ve sağlık sonuçları üzerinde dikkate değer etkileri bulunmaktadır. Ancak sağlık hizmetlerinin ekip halinde sunulan karmaşık ve dinamik nitelikte hizmetler olması nedeniyle sağllk profesyonellerine informal ilişkileri teşvik edici bir alan - panoptikonun sağlık sisteminin her alanında olmadığ 1 bir alan oluşturmak yöneticiler ve karar vericiler tarafindan önemsenmelidir.

\section{KAYNAKÇA}

Abal1, T. Z. (2018). Mahremiyet ve gözetim ilişkisi bağlaminda aile hekimliği bilgi sistemine dair bir değerlendirme (Yüksek Lisans Tezi). Adnan Menderes Üniversitesi, Aydın.

Akerlof, G. A. \& Kranton, R. E. (2016). Kimlik iktisadl: kimliklerimiz, işimizi, ücretimizi ve refahımızı nasıl şekillendiriyor? (C. Madenci, Çev.). Ankara: Efil Yayınları.

Akyazı, A. (2019). Mahremiyetin dönüşümü: ünlülerin instagram paylaşımları üzerine bir araştırma. Gaziantep University Journal of Social Sciences, 18(1), 197-216.

Bauman, Z. (2007). Modernite ve holocaust. (S. Sertabiboğlu, Çev.). İstanbul: Versus Kitap.

Bauman, Z. (2017a). Akışkan modernite (İkinci basım). (S. O. Çavuş, Çev.). İstanbul: Can Sanat Yayınları.

Bauman, Z. (2017b). Azınlı̆̆ın zenginliği hepimizin çıkarına mıdır? (Üçüncü basım). (H. Keser, Çev.). İstanbul: Ayrıntı Yayınları.

Bauman, Z. (2018a). Sosyolojik düşünmek (Onyedinci basım). (A. Yılmaz, Çev.). İstanbul: Ayrıntı Yayınları.

Bauman, Z. (2018b). Retrotopya. (A. Karatay, Çev.). İstanbul: Sel Yayıncılık.

Bauman, Z. \& Lyon, D. (2018). Akışkan Gözetim (Üçüncü basım). (E. Yılmaz, Çev.). İstanbul: Ayrıntı Yayınları.

Beck, U. (1992). Risk cociety: Towards a New Modernity. Londra: Sage.

Bentham, J. (1995). The panoptic writings, ed Miran Božovič. London: Verso.

Beyatlı, H. Z. (2017). Hastane ve sağlık işletmeleri yönetimi. Ankara: Nobel Akademik Yayıncılık.

Bhatnagar S. (2013). Who is really afraid of death? Indian Journal Palliat Care, 19, 81-2.

Black, K. (2007). Health care professionals' death attitudes, experiences, and advance directive communication behavior. Death Studies, 31, 563-72.

Boone, L. E. \& Kurtz, D. L. (2016). Contemporary business (14th edition). İçinde A. Yalçın (Çev. Ed.). Çağdaş İşletme (252-283). Ankara: Nobel Akademik Yayıncilik.

Bozalp, M. (2018). Gözetim Toplumundaki Yapısal Değişim ve Dönüşümler. Amme Ídaresi Dergisi, 51(1), 27-69. 
Bulut, S. (2019). Söylemin kapatılma ve açımlama savaşımında Edward Snowden. Etkileşim, 3, 128-141.

Castel, E. S., Ginsburg, L. R., Zaheer, S. \& Tamim, H. (2015). Understanding nurses' and physicians' fear of repercussions for reporting errors: clinician characteristics, organization demographics, or leadership factors? BMC Health Services Research, 15(1), 1-10.

Coase, R. H. (1937). The nature of the firm. Economica, 4(16), 386-405.

Couch, D., Han, G. S., Robinson, P. \& Komesaroff, P. (2015). Public health surveillance and the media: a dyad of panoptic and synoptic social control. Health psychology and behavioral medicine, 3(1), 128-141.

Dahlen, H. G. \& Caplice, S. (2014). What do midwives fear? Women and birth, 27(4), 266-270.

De Choudhury, M., Meredith, R. \& Morris, W. (2014). Seeking and sharing health information online: comparing search engines and social media. Paper presented at_the 32nd Annual ACM Conference on Human Factors in Computing Systems, New York, USA, 1365-1376.

Deffner, J.M. \& Bell, S. K. (2005). Nurses' death anxiety, comfort level during communication with patients and families regarding death, and exposure to communication education: a quantitative study. Journal for nurses in professional development, 21, 19-23.

Durutürk, B. (2018). Michel Foucault'nun iktidar ve özne kavramlarına bir bakış: gözetim toplumu. Üçüncü sektör sosyal ekonomi, 53(3), 959-972.

Eckermann, L. (1997). Foucault, embodiment and gendered subjectivities: The case of voluntary selfstarvation. In A. Petersen \& R. Bunton (Eds.), Foucault, health and medicine (151-172). New York, NY: Routledge.

Ettinger, K. E. (1965). International handbook of management. USA: McGraw-Hill.

Foucault, M. (1979). Discipline and punish: the birth of the prison. New York: Vintage Books.

Foucault, M. (1980). The eye of power. In, C. Gordon (Ed.), Power/knowledge: selected interviews and other writings (1972-1977) (pp. 146-165). New York: Pantheon Books.

Foucault, M. (2002). Kliniğin Doğuşu. (Ş. Ünsaldı, Çev.). Ankara: Epos Yayınları.

Goffman, E. (1959). The presentation of self in everyday life. Garden City: Doubleday Anchor.
Graban, M. (2011). Yalın hastane: kalite, hasta güvenliği ve çalışan memnuniyetini artırmak. (P. Şengözer, Çev.). İstanbul: Optimist Yayınları.

Haggerty, K. D. \& Ericson, R. V. (2000). The surveillant assemblage. British Journal of Sociology, 51 (4), 605622 .

Harari, Y. N. (2016). Homo deus. Yarının kisa bir tarihi. (P. N. Taneli, Çev.). İstanbul: Kolektif Kitap.

Huxley, A. (2018). Cesur yeni dünya (25. Bask1). (Ü. Tosun, Çev.). İstanbul: İthaki Yayınları.

Johnson, D. \& Regan, P. (2014). Introduction. In, D. Johnson \& P. Regan (Eds.), Transparency and surveillance as sociotechnical accountability: a house of mirrors (pp. 1-24) Abingdon: Routledge.

Kıdak, L. B. \& Demir, H. (2018). Küresel Sağlık Politikaları. İçinde D. Tengilimoğlu (Ed.), Sağlık Politikası (ss. 159-181). İstanbul: Nobel Akademik Yayıncilik.

Koçel, T. (2015). İşletme yöneticiliği (On Altıncı Baskı). İstanbul: Beta Yayınları.

Koontz, H. \& Weihrich, H. (1988). Management (Dokuzuncu bask1). USA: McGraw-Hill.

Kumar, S. P., D'Souza, D. \& Sisodia, V. (2013). Healthcare professionals' fear of death and dying: 1mplications for palliative care. Indian J Palliat Care, 19(3), 196-98.

Lashmar, P. (2017). No more sources? Journalism Practice, 11(6), 665-688.

Lianos, M. (2003). Social control after foucault. Surveillance \& Society, 1(3), 412-430.

Manokha, I. (2018). Article surveillance, panopticism, and self-discipline in the digital age. Surveillance \& Society, 16(2), 219-237.

Maslow, A. H. (1954). Motivation and personality. New York: Harper \& Row Publishers.

Mathiesen, T. (1997). The viewer society: Michel Foucault's "panopticon" revisited. Theoretical Criminology, 1(2), 215-34.

McGregor, D. (1960). The human side of enterprise. New York: McGraw-Hill.

Mintzberg, H. (2014). Örgütler ve yapıları. Aypay, A. (Çev. Ed.). İstanbul: Nobel Akademik Yayıncılık.

Nia, H. S., Lehto, R. H. \& Ebadi, A. (2016). Death anxiety among nurses and health care professionals: A review article. International journal of community based nursing and midwifery, 4(1), 2-10.

Öztürk, İ. D. (2019). Panoptikon 2.0: Alternatif Medya ve Karşı Gözetim (Kitap İncelemesi). Erciyes İletişim Dergisi, 6(1), 701-712. 
Peck, M. R. (2009). Personal death anxiety and communication about advance directives among oncology social workers. Journal of social work in end-of-life \& palliative care, 5, 49-60.

Pen American Center (2013). Chilling effects: nsa surveillance drives writers to self-censor. https://pen.org/sites/default/files/Chilling\%20Effects_ PEN\%20American.pdf. Erişim Tarihi: 20.12.2018.

Shortell, S. M. \& Kaluzny, A. D. (2006). Health care management: organization design and behavior. İçinde S. M. Shortell \& A. D. Kaluzny (Eds.). Organization theory and health services management (ss. 5-41). USA: Thomson Delmar Learning.

Thaler, R. \& Sunstein, C. R. (2017). Dürtme: sağlık, zenginlik ve mutlulukla ilgili kararları uygulamak. Günsel, E. (Çev.). İstanbul: Pegasus Yayınları.

Todaro, M. P. \& Smith, S. C. (2012). Economic development (11th ed.). Boston: Pearson Yayınları.

Toffler, A. (2008). Üçüncü Dalga. (S. Yeniçeri, Çev.). İstanbul: Koridor Yayıncılık.

Toohill, J., Fenwick, J., Sidebotham, M., Gamble, J. \& Creedy, D. K. (2018). Trauma and fear in Australian midwives. Women and Birth, 32(1), 64-71.

Ulutaş, Ç. Ü. (2002). Proleterleşme ve profesyonelleşme tartışmaları ışı̆̆ında Türkiye'de sağlı emek sürecinin dönüşümü. Ankara: NotaBene Yayınları.

Van Haute, D., Roets, G., Alasuutari, M. \& Vandenbroeck, M. (2018). Managing the flow of private information on children and parents in poverty situations: Creating a panoptic eye in interorganizational networks? Child and Family Social Work, 23(3), 427-434.

Westin, A. (1967). Privacy and freedom. New York: Atheneum.

WHO (2009). System thinking for health system strengthening,

http://apps.who.int/iris/bitstream/10665/44204/1/9789 241563895_eng.pdf?ua=1. Erişim Tarihi: 10.12.2018.

Williams, C. (2007). Management (Dördüncü Baskı). Canada: Pre Press.

Williamson, O. E. (1975). Transaction-cost economics: the governance of contractual relations. Journal of Law and Economics, 22(2), 233-261. 